\title{
33. RADIOLARIA FROM THE SOUTHERN INDIAN OCEAN, DSDP LEG 26
}

\author{
W. R. Riedel and Annika Sanfilippo, Scripps Institution of Oceanography, La Jolla, California
}

\section{INTRODUCTION}

The localities of the drilling sites occupied during Leg 26 of the Deep Sea Drilling expedition, which were examined for radiolarians, are as follows:

Site 250:

5119 meters

Site 251:

3489 meters

Site 252:

5032 meters

Site 253:

1962 meters

Site 254:

1253 meters

Site 255:

1144 meters

Site 256:

5361 meters

Site 257:

5278 meters

Site 258:

2793 meters

$33^{\circ} 27.74^{\prime} \mathrm{S}, \quad 39^{\circ} 22.15^{\prime} \mathrm{E}$, water depth

$36^{\circ} 30.26^{\prime} \mathrm{S}, \quad 49^{\circ} 29.08^{\prime} \mathrm{E}$, water depth

$37^{\circ} 02.44^{\prime} \mathrm{S}, \quad 59^{\circ} 14.33^{\prime} \mathrm{E}$, water depth

$24^{\circ} 52.65^{\prime} \mathrm{S}, \quad 87^{\circ} 21.97^{\prime} \mathrm{E}$, water depth

$30^{\circ} 58.15^{\prime} \mathrm{S}, \quad 87^{\circ} 53.72^{\prime} \mathrm{E}$, water depth

$31^{\circ} 07.87^{\prime} \mathrm{S}, \quad 93^{\circ} 43.72^{\prime} \mathrm{E}$, water depth

$23^{\circ} 27.35^{\prime} \mathrm{S}, 100^{\circ} 46.46^{\prime} \mathrm{E}$, water depth

$30^{\circ} 59.16^{\prime} \mathrm{S}, 108^{\circ} 20.99^{\prime} \mathrm{E}$, water depth

$33^{\circ} 47.69^{\prime} \mathrm{S}, 112^{\circ} 28.42^{\prime} \mathrm{E}$, water depth

Most of the radiolarian assemblages obtained fall into two categories-(1) cool-water, Neogene assemblages that are difficult to correlate with warm-water sequences, partly because of the small numbers of species present, and (2) Cretaceous assemblages that are difficult to date because of the fragmentary state of present understanding of the radiolarian stratigraphy of that period. Having insufficient time to tackle both of these problems, we have chosen to concentrate on the latter. Thus we treat the Cenozoic occurrences only cursorily and attack the Cretaceous problem by describing a coarse radiolarian zonation which divides that period into seven parts.

\section{OCCURRENCES OF RADIOLARIANS}

In this section, and in subsequent tabulations, the following abbreviations are used to indicate preservation and abundance of radiolarians: $P$ (poorly preserved), M (moderately preserved), G (well preserved), A (abundant), C (common), R (rare), + or vR (very rare), ? (doubtful identification), - (looked for, and not found), and $\times$ (not found, but absence may be due to some secondary factor such as solution, alteration, excessive sieving of the assemblage, etc.).

\section{Site 250}

Radiolarians occur in all samples examined from Cores 1-3 of Hole 250, with the following abundances and preservation: Samples 250-1-1, 50-54 cm (F, M); -11, 65-67 cm (R, P); -1-3, 130-134 cm (R, M); -1-6, 49-51 $\mathrm{cm}(\mathrm{R}, \mathrm{M}) ;-1, \mathrm{CC}(\mathrm{R}, \mathrm{M})$; -2-2, 55-59 cm (R, M); -2-3,
$55-59 \mathrm{~cm}(\mathrm{R}, \mathrm{M}) ;-2-6,55-59 \mathrm{~cm}(\mathrm{R}, \mathrm{M}) ;-2, \mathrm{CC}(\mathrm{R}, \mathrm{P})$; $-3-1,54-58 \mathrm{~cm}(\mathrm{~F}, \mathrm{P})$; -3-3, 53-57 cm (F, P); -3, CC (R, P).

Of approximately 68 samples examined from Cores 125 of Hole $250 \mathrm{~A}$, only the following contained radiolarians: Samples 250A-1-2, 55-59 cm (R, P); -1, CC $(\mathrm{R}, \mathrm{P}) ;-3-5,54-58 \mathrm{~cm}$ (vR pyritized fragments); -5 , CC (vR pyritized fragments); -6-2, 59-64 $\mathrm{cm}$ (vR pyritized fragments); -6-4, 55-59 cm (vR pyritized fragments); -8 , CC (vR, M); -22, CC (F, M); -23-1, 28-32 cm (R, M); $-23-2,63-65 \mathrm{~cm}(\mathrm{R}, \mathrm{P})$; -24-1, 101-106 cm (R, M); -24-2, $46-51 \mathrm{~cm}(\mathrm{~F}, \mathrm{P})$.

Assemblages down through Core 250-3 are apparently late Neogene in age (based principally on the occurrence of artiscins lacking tubercles), Core 250A-8 appears to be Cenozoic, but has an assemblage too sparse for a more precise age assignment, and assemblages from Core 250A-22 downward include Amphipyndax stocki and are thus evidently Cretaceous (Barremian or later).

\section{Site 251}

Occurrence of radiolarians in samples examined from this site is as follows: Samples $250-1-2,107-111 \mathrm{~cm}$ (C, G); -1, CC (C, G); -2-1, 59-63 cm (F, G); -2-5, 55-59 cm (R, P); -2, CC (C, G); -3-2, 54-59 cm (F, M); -3, CC (C, G); -4-2, 55-59 cm (F, M); -4-5, 55-59 cm (F, M); -4, CC (C, G); -5-2, 55-59 cm (C, M); -5-5, 55-59 cm (F, M); -5, CC (C, G); -6-2, 55-59 cm (R, M); -6-5, 55-59 cm (F, M); -6 , CC (C, G); -7-2, 55-59 cm (F, M); -7-5, 55-59 cm (F, G); -7, CC (C, G); -8-2, 55-59 cm (C, G); -8-5, 55-59 cm (C, G); -8, CC (C, G); -10-2, 55-59 cm (R, P); -10-4, 55$59 \mathrm{~cm}(\mathrm{R}, \mathrm{P}) ;-10, \mathrm{CC}(\mathrm{R}, \mathrm{P})$. Samples 251A-1-2, 55-59 $\mathrm{cm}(\mathrm{R}, \mathrm{P}) ;-1-5,55-59 \mathrm{~cm}(\mathrm{R}, \mathrm{P})$; -1, CC (R, P); -2-2, 55$59 \mathrm{~cm}(\mathrm{R}, \mathrm{P})$; -2-4, 55-59 cm (R, P); -2, CC (R, P); -4-2, 55-59 cm (R, P); -4-5, 55-59 cm (R, P); -4, CC (R, P); -52, 55-59 cm (R, P); -5-5, 55-59 cm (R, P); -5, CC (R, P); 6-2, 55-59 cm (R, P); -6-5, 55-59 cm (R, M); -6, CC (R, M); -7-2, 55-59 cm (R, P); -7-5, 55-59 cm (R, P); -7, CC $(\mathrm{R}, \mathrm{P})$; -9-2, 85-89 cm (R, P); -9-5, 55-59 cm (R, P); -9, CC (R, P); -10-2, 55-59 cm (R, P); -10-5, 55-59 cm (RP); -10, CC (R, M); -11-2, 55-59 cm (R, P); -11, CC (F, M); $-12-2,55-59 \mathrm{~cm}(\mathrm{R}, \mathrm{P}) ;-12-5,55-59 \mathrm{~cm}(\mathrm{R}, \mathrm{P}) ;-12$, CC (R, P); -13-2, 83-88 cm (R, P, pyritized); -13-4, 55-59 $\mathrm{cm}$ (None); -13, CC (None), -14, CC (R, P, pyritized); $15-2,55-59 \mathrm{~cm}$ (None); $-15, \mathrm{CC}(\mathrm{R}, \mathrm{P}) ;-16-2,55-59 \mathrm{~cm}$ ( $\mathrm{R}$, P, pyritized).

Approximately 28 samples examined below this, through Core 251A-29, contain no radiolarians, except as follows: Samples 251A-21, CC (R, P, pyritized) and -23 , CC ( R, P, pyritized).

All assemblages found are apparently Neogene, but we have not been able to determine ages more precisely. 


\section{Site 252}

In 5 samples examined from Core 252-2, radiolarians are abundant and well preserved, and in 19 samples from Cores 252-3 through 252-7 they are common, and moderately to well preserved. The assemblage in $252-7$, $\mathrm{CC}$ includes approximately equal numbers of rare Ommatartus antepenultimus, $O$. avitus, and $O$. penultimus, common Stichocorys delmontensis, very rare $S$. peregrina, and rare Phormostichoartus corona, and thus can be assigned tentatively to the Ommatartus penultimus Zone (late late Miocene). Zonal boundaries are difficult to determine in the samples above this, but the top of Core 252-2 contains Stichocorys peregrina without $S$. delmontensis and also rare specimens of the form ancestral to Pterocorys hertwigii, with three or fewer longitudinal ribs, indicating a probably Pliocene age.

\section{Site 253}

The uppermost sample examined from Core 253-1 contains rare, corroded, unidentifiable radiolarian fragments, and 13 samples from Cores $253-1,-2,-3,-4$, $-16,-17$, and -18 contain no radiolarians. Samples $253-$ $18-3,136-140 \mathrm{~cm}$ through $253-20$, CC contain rare to few, moderately to poorly preserved sparse assemblages of mostly small radiolarians including rare Lophocyrtis biaurita, Theocorys anapographa, and Theocampe urceolus, and very rare Phormocyrtis striata striata, and small Lychnocanoma bellum and Podocyrtis papalis, indicating either the Theocotyle cryptocephala cryptocephala Zone or the upper part of the Phormocyrtis striata striata Zone (early middle Eocene). None of the 41 samples examined from Cores 253-21 through -57 contain radiolarians, except for sparse fragmentary forms insufficient for biostratigraphic interpretation in Sample 253-36, CC.

\section{Site 254}

No radiolarians were found in any of the 32 samples examined from Cores 254-1 through -27.

\section{Site 255}

Occurrence of radiolarians in samples from this site is as follows: Samples 255-3-1, 104-107 cm (R, P); -4-1, 57$59 \mathrm{~cm}(\mathrm{R}, \mathrm{P})$; $-4-2,55-57 \mathrm{~cm}(\mathrm{R}, \mathrm{P}) ;-5-1,54-56 \mathrm{~cm}(\mathrm{R}$, $\mathrm{P}) ;-5$, CC (None); -6, CC (R, P); -7, CC (None); -9-1, $115-117 \mathrm{~cm}(\mathrm{~F}, \mathrm{P}) ;-9, \mathrm{CC}(\mathrm{R}, \mathrm{P}) ;-10, \mathrm{CC}(\mathrm{F}, \mathrm{M}) ;-11-1$, $72-76 \mathrm{~cm}$ (None); -11, CC (R, P). All of the assemblages appear to be Cretaceous, but are not adequate for more precise interpretation.

\section{Site 256}

Of the 19 samples examined from Core 256-1 through -5 , none has radiolarians except Sample 256-1-3, 55-59 $\mathrm{cm}$, which contains rare corroded fragments. The Cretaceous section below that contains radiolarians as follows: Samples 256-6-1, 22-26 cm (F, M); -6-2, 54-58 $\mathrm{cm}(\mathrm{C}, \mathrm{M}) ; 6-3,55-59 \mathrm{~cm}(\mathrm{C}, \mathrm{M}) ;-6-5,55-59 \mathrm{~cm}(\mathrm{C}, \mathrm{M})$; $-6-6,90-92 \mathrm{~cm}(\mathrm{~F}, \mathrm{M}) ;-6-6,125-127 \mathrm{~cm}(\mathrm{~F}, \mathrm{M}) ;-6$, CC $(\mathrm{C}, \mathrm{M}) ;-7-1,30-34 \mathrm{~cm}$ green $(\mathrm{F}, \mathrm{P}) ;-7-1,30-34 \mathrm{~cm}$ red (F, M); -7-2, 102-106 cm (R, M); -7-3, 11-13 cm (R, M); -
$7-3,82-84 \mathrm{~cm}$ (None); -7, CC (None); -8-1, 68-73 cm (None); -8-2, 55-60 cm (None); -8-3, 54-58 cm (None); 8-4, 55-59 cm (None); -8-5, 55-59 cm (R, P); -8-6, 55-59 cm (R, P); -8, CC (R, P); -9-1, 114-118 cm (None).

Species occurrences listed in Table 2 indicate that Core 256-6 is probably near the top of the Dictyomitra veneta Zone (approximately Albian-Coniacian), or in the Artostrobium urna Zone (approximately ConiacianCampanian).

\section{Site 257}

Rare, poorly to moderately preserved radiolarians occur in four samples examined from Core 257-1. The only recognizable species are rare Cyclampterium (?) milowi and very rare Thyrsocyrtis triacantha, indicating an age near the Eocene-Oligocene boundary (late Thyrsocyrtis bromia Zone or early Theocyrtis tuberosa Zone).

Radiolarians are absent in seven samples from Core 257-3 through the upper half of Core 257-4. Below that, they occur as follows: Samples $257-4-3,126-130 \mathrm{~cm}(\mathrm{R}$, M); -4-4, 84-88 cm (F, G); -4, CC (F, M); -5-2, 2-6 cm (R, M); -5, CC (R, M); -6-1, 85-89 cm (None); -6, CC (vR, P); -7-2, 26-30 cm (None); -7-5, 30-34 cm (vR, P); $-7, \mathrm{CC}(\mathrm{vR}, \mathrm{P})$. Radiolarians are absent from Cores 257-8 through 10, with the exception of very rare, poorly preserved specimens in Sample 257-9, CC.

The best-preserved and most diverse radiolarian assemblage at this site occurs in Section 257-4-4. It includes rare Pseudoaulophacus superbus, few Amphipyndax stocki, few representatives of the Stichomitra asymbatos group, very rare Cyrtocalpis operosa, and very rare Dictyomitra sp. cf. D. regina, indicating a stratigraphic position approximately in the upper part of the Dictyomitra veneta Zone (approximately TuronianConiacian).

\section{Site 258}

In seven samples examined from Cores 258-1 through -2 , radiolarians are rare, poorly preserved. In Sample $258-3-1,55-59 \mathrm{~cm}$ they are very rare, poorly preserved, and below that through Core 258-4 they are absent. Radiolarian occurrences in subsequent cores are as follows: Samples 258-5-1, 103-107 cm (F, M); -5-2, 60-64 $\mathrm{cm}(\mathrm{F}, \mathrm{M}) ;-5-3,55-59 \mathrm{~cm}(\mathrm{~F}, \mathrm{M}) ;-5$, CC (F, M); -6-2, 66-70 cm (R, M); -6-3, 54-59 cm (R, M); -6-4, 51-55 cm (R, M); -6-5, 55-59 cm (R, M); -6, CC (F, G); -7-1, 105$107 \mathrm{~cm}(\mathrm{~F}, \mathrm{G}) ;-7-2,55-60 \mathrm{~cm}(\mathrm{~F}, \mathrm{G}) ;-7-3,89-93 \mathrm{~cm}(\mathrm{~F}$, G); - 7, CC (F, G); -8, CC (F, G); -9-1, 50-55 cm (C, G); 9, CC (None); -10-1,134-139 cm (F, G); -10, CC (R, M); $-11-2,44-48 \mathrm{~cm}(\mathrm{~F}, \mathrm{M}) ;-11-3,57-61 \mathrm{~cm}(\mathrm{~F}, \mathrm{M}) ;-11, \mathrm{CC}$ (R, P); -12-1, 33-36 cm (R, M); -12-2, 60-64 cm (F, G); $12-4,127-131 \mathrm{~cm}(\mathrm{~F}, \mathrm{G}) ;-12-5,48-50 \mathrm{~cm}(\mathrm{~F}, \mathrm{M}) ;-12-6$, 62-66 cm (F, M); -12, CC (F, M); -13-2, 48-52 cm (C, M); -13-4, 65-69 cm (R, M); -13, CC (R, M); -14-1, 19-21 $\mathrm{cm}(\mathrm{R}, \mathrm{M})$; -14-1, 119-121 cm (R, P); -14, CC (R, M); $15-2$, 4-8 cm (C, M); -15-3, 49-51 cm (None); -15-4, 73$78 \mathrm{~cm}(\mathrm{R}, \mathrm{P})$; -15-5, 65-69 cm (R, P); -15, CC (F, M); 16-2, 55-59 cm (R, M); -16-5, 55-59 cm (F, M); -17-2, 55$59 \mathrm{~cm}(\mathrm{R}, \mathrm{P})$; - 17-4, 53-57 cm (F, M); -18-2, 55-59 cm (R, M); -18-4, 134-138 cm (R, M); -20-1, 81-84 cm (R, M); $20, \mathrm{CC}(\mathrm{R}, \mathrm{P}) ;-21-1,54-58 \mathrm{~cm}(\mathrm{R}, \mathrm{M}) ;-22-2,56-59 \mathrm{~cm}$ (R, P); -22-4, 55-59 cm (F, P, calcite casts); -23-2, 56-59 
cm (None); -24-2, 50-54 cm (R, P); -24-5, 121-125 cm (None); -25-4, 32-34 cm (None).

In Hole $258 \mathrm{~A}$, radiolarian occurrences are as follows: Samples 258A-1-1, 27-31 cm (R, M); -1-2, 91-95 cm (R, M); -3-2, 54-58 cm (None); -3-3, 53-57 cm (R, P); -3-6, 23-25 cm (None); -4-1, 95-99 cm (None); -4-6, 6-8 cm (vR, M); -5-1, 48-52 cm (None); -5-6, 58-62 cm (vR, P); $-6-3,87-91 \mathrm{~cm}$ (vR, M); -6-6, 55-59 cm (None); -7-1 87-91 $\mathrm{cm}(\mathrm{R}, \mathrm{P}) ;-7-5,36-40 \mathrm{~cm}$ (vR, P); -8-3, 40-44 cm (R, P); $-8-5,36-41 \mathrm{~cm}$ (None). In eight samples from -8 , CC through $-9, \mathrm{CC}$, radiolarians are few to common, moderately preserved.

The radiolarians in Cores 258-1 through 258-4 and $258 \mathrm{~A}-1$ through $258 \mathrm{~A}-8-5$ are fragmentary, and insufficient for any more precise age assignment than Cenozoic. In the Cretaceous portion of Hole 258A (258A-8, CC through Core 258A-9), the radiolarians are not sufficiently well preserved or diverse for stratigraphic interpretation. Cores 258-5 through -17 are evidently somewhat older than Core 256-6 and are assignable approximately to the Dictyomitra veneta Zone (approximately Albian-Coniacian) on the basis of species occurrences indicated in Table 2. In Cores 258 18 through -21 radiolarians are too few for stratigraphic interpretation, and in Core 258-22 they are poorly preserved and filled with a mineral resembling glauconite.

\section{CRETACEOUS ZONATION}

As groundwork for the interpretation of the Cretaceous radiolarians of Leg 26, we have made a survey of Cretaceous and Late Jurassic assemblages available to us from other sources, to determine the possibility of formulating a coarse, widely applicable zonation.

Several researchers have recently made advances in Cretaceous radiolarian stratigraphy (Foreman, 1968, 1973b; Moore,1973; Pessagno, in press), and we have benefited from their work. Most of the work of Foreman and Pessagno has been based on wellpreserved assemblages investigated with a high degree of taxonomic discrimination, often with a scanning electron microscope. We here attempt a coarser zonation, based on broadly defined species or groups of species which are recognizable in poorly preserved assemblages by normal transmitted-light microscopy.

Most of the samples on which our Cretaceous radiolarian zonation is based are from DSDP cores (predominantly from the northwestern Pacific Leg 17, but also some from the Caribbean Leg 15, the northwestern Atlantic Leg 11, and the Indian Ocean Legs 25 and 27), to which have been added some samples from land-based localities in Europe, the Caribbean, Australia, Indonesia, and California, as listed below.

Beets R60-161: Collected by T. B. Roep approximately $1.0 \mathrm{~km}$ north of Tirieza Baja, in the Xiquena area east of Velez Blanco, southeast Spain (Roep, 1972). From D. J. Beets. Aptian or Albian (Roep, personal communication). According to P. H. Roth (personal communication), a late Barremian age is indicated by calcareous nannofossils including Nannoconus bucheri, N. colomi, N. truitti, N. elongatus, Watz- naueria barnesae, Rhagodiscus asper, Parhabdolithus embergeri, Micrantholithus hoschulzi, Lithraphidites carniolensis, Vagalapilla cf. elliptica (Staurolithites crux of other authors), Braarudosphaera bigelowi, Biscutum supracretaceum, Manivitella pemmatoidea, Parhabdolithus splendens, and Micrantholithus cf. vesper.

DSDP 99A-8-1, $112-116 \mathrm{~cm}: 23^{\circ} 41.14^{\prime} \mathrm{N}, 73^{\circ} 50.99^{\prime} \mathrm{W}$; water depth 4914 meters. Tithonian to Valanginian (Habib, 1972; Wilcoxon, 1972; Bukry, 1972).

DSDP $146-15-5,15-25 \mathrm{~cm}: 15^{\circ} 06.99^{\prime} \mathrm{N}, 69^{\circ} 22.67^{\prime} \mathrm{W}$; water depth 3949 meters. Maastrichtian (Premoli Silva and Bolli, 1973).

DSDP 146-27-1, 1-11 cm: Campanian (Premoli Silva and Bolli, 1973).

DSDP 146-30-2, 79-85 cm: Approximately Santonian (Premoli Silva and Bolli, 1973).

DSDP 164-11-1, 128-130 cm; 164-16-1, 141-143 cm. $13^{\circ} 12.14^{\prime} \mathrm{N}, 161^{\circ} 30.98^{\prime} \mathrm{W}$; water depth 5499 meters: Coniacian or Santonian (Moore, 1973).

DSDP $167-60-2,128-130 \mathrm{~cm}: 07^{\circ} 04.1^{\prime} \mathrm{N}, 176^{\circ} 49.5^{\prime} \mathrm{W}$; water depth 3176 meters. Late Turonian (Roth, 1973).

DSDP 167-61-1, 132-134 cm; 167-61-2, 104-106 $\mathrm{cm}$ : Early Cenomanian (Roth, 1973).

DSDP $167-62-2,136-138 \mathrm{~cm} ; 167-64-5,15-17 \mathrm{~cm}$ : Late Albian or early Cenomanian (Roth, 1973).

DSDP 167-67-3, 101-103 cm; 167-67-4, 55-56 cm:Albian (Roth, 1973).

DSDP 167-69-3, 36-38 cm; 167-70-2, 34-40 cm; 167-70-4, 140-142 cm: Aptian or early Albian (Roth, 1973).

DSDP 167-72-2, 48-50 cm; 167-72, CC: Barremian (Roth, 1973).

DSDP 167-73-2, 30-32 cm; 167-74-2, 74-76 cm: Hauterivian (Roth, 1973).

DSDP 167-76-2, 65-67 cm: Late Valanginian or early Hauterivian (Roth, 1973).

DSDP 167-88, CC; 167-93-2, 22-24 cm: Late Berriasian or early Valanginian (Roth, 1973).

DSDP 167-94-2, 40-42 cm: Late Tithonian or early Berriasian (Roth, 1973).

DSDP 249-24-1, 106-108 cm: $29^{\circ} 56.99^{\prime} \mathrm{S}, 36^{\circ} 04.62^{\prime} \mathrm{E}$; water depth 2088 meters.

DSDP $261-12$, CC: $12^{\circ} 56.83^{\prime} \mathrm{S}, 117^{\circ} 53.56^{\prime} \mathrm{E}$; water depth 5687 meters.

Gearle CC-16 and CC-19: Type section of the Gearle Siltstone, east of Remarkable Hill, Carnavon Basin, Western Australia. Sample CC-16 is $117 \mathrm{ft}$ above the base of the Gearle Siltstone, and CC-19 is $460 \mathrm{ft}$ above the base. From D. J. Belford. Lat $22^{\circ} 53^{\prime}$ S, long $114^{\circ} 07^{\prime} \mathrm{E}$ (Condon et al., 1956). Albian to Turonian (McWhae et al., 1958).

Pt. Sal: Limestone nodule from gentle beach cliff approximately $0.6 \mathrm{~km}$ north-northeast of Point Sal, California. From C. A. Hopson and D. E. Karig. Additional material collected, under Hopson's guidance, as WR 73-4 and 73-5.

Rotti 150: Near Bebalain, on the island of Rotti, near Timor (Tan Sin Hok, 1927; Riedel, 1953). From H. A. Brouwer and H. J. de Wijs. According to D. Bukry (personal communication), the calcareous nannofossils in this sample include Cretarhabdus crenulatus, Eiffellithus turriseiffeli, Manivitella pem- 
matoidea, Parhabdolithus embergeri, Vagalapilla matalosa, Watznaueria barnesae, and W. biporta, indicating an Aptian to Turonian (probably Albian to Turonian) age. Other samples of Tan Sin Hok from Rotti (no. 149, 154, and 384) contain rather similar radiolarian assemblages and are probably of approximately the same age.

WRE 67-42: Eastern Röthelbach, Dalsenalm, Reichenhall, Bavaria. The sample is from approximately 7 meters above sample 2030 of Herm (1962), who kindly assisted in its collection. Late Campanian.

WRE 67-74: Roadcut on northwest side of the road approximately $0.8 \mathrm{~km}$ northeast of Santa Anna (near Caltabellotta, Sicily) toward Molino Cifota (Folio 266 I SO of the Carta d'Italia, Istituto Geografico Militare). Tithonian or lowermost Berriasian (P. H. Roth, personal communication), indicated by the calcareous nannofossils which include Watznaueria barnesae, W. communis, W. britannica, Rhagodiscus rugosus, Cyclagelosphaera margarelli, C. deflandrei, Diazomatolithus lehmani, and Nannoconus colomi.

WRTR 57: Near the base of the Globotruncana concavata Zone (early Santonian), from a depth of $8965 \mathrm{ft}$ in Trinidad Leaseholds well Marac 1, Trinidad (coordinates N:152141 links, E:424447 links). From J. B. Saunders. Foraminifera from this well are referred to by Bolli (1957).

This attempt at a Cretaceous radiolarian zonation rests on much less secure foundations than does the zonation of the Cenozoic. The fundamental reason for this is the lack of well-preserved assemblages, particularly in long sequences. Thus it is not yet possible to determine phyletic relationships, which would greatly aid the stratigraphy. Other factors are the uncertainty of some age assignments based on calcareous microfossils, and our scant understanding of the geographic locations of parts of the sea floor through the Cretaceous, with the resulting difficulty in determining which differences between assemblages may be due to biogeography, rather than age.

Except where the order of superposition of the samples is known, their sequential arrangement in Table 1 depends largely on comparison of the radiolarian assemblages. The extent to which this order is supported or contradicted by other evidence is shown by age assignments in the sample list, above.

The zones proposed here are described below, from youngest to oldest. The top of each zone is defined by the base of the zone above it.

\section{Theocapsomma comys Zone}

Base defined by the earliest morphotypic appearance of Theocapsomma comys, which is approximately synchronous with the earliest appearances of Rhopalosyringium antirrhopum and Theocampe ixys and the latest occurrences of Pseudoaulophacus pargueraensis and Dictyomitra torquata. The top of the zone cannot yet be precisely defined, but may be taken as the faunal change occurring at the Maastrichtian/Paleocene boundary described by Foreman (1968).

\section{Amphipyndax enesseffi Zone}

Base defined by the earliest morphotypic appearance of Amphipyndax enesseffi, which is approximately synchronous with the latest occurrence of Dictyocephalus sp. (Pessagno, 1963).

The zone appears to include the latest occurrence of Clathropyrgus titthium.

\section{Artostrobium urna Zone}

Base defined by the earliest morphotypic appearance of Artostrobium urna, which is approximately synchronous with the latest occurrence of Cyrtocalpis operosa.

Events within the zone include the latest occurrence of Theocorys antiqua, the earliest appearances of Dictyocephalus sp. (Pessagno, 1963), Clathropyrgus titthium, Pseudoaulophacus pargueraensis, P. superbus, Theocampe salillum, and Afens liriodes, and the entire range of Clathropyrgus bumastus.

\section{Dictyomitra veneta Zone}

Base defined by the latest occurrence of Sphaerostylus lanceola, which is approximately synchronous with the earliest appearance of Archaeospongoprunum cortinaensis.

Events within the zone include the earliest appearance of the genus Bathropyramis, the latest occurrences of Acanthocircus dizonius, Lithocampe elegantissima, Stichocapsa tenuis, and Dictyomitra lilyae, and the entire ranges of Dictyomitra macrocephala and D. veneta.

\section{Stichocapsa tenuis Zone}

Base defined by the earliest morphotypic appearance of Stichocapsa tenuis.

Events within the zone include the latest occurrences of Lithocampe mediodilatata, L. perampla, Acanthocircus carinatus, Hemicryptocapsa spp. cf. H. capita, Dictyomitra boesii, Staurosphaera septemporata, and Sethocapsa trachyostraca, and the earliest appearances of Dictyomitra lilyae, Eucyrtis bulbosus, and Amphipyndax stocki.

\section{Staurosphaera septemporata Zone}

Base defined by the earliest morphotypic appearance of Staurosphaera septemporata.

The zone includes the earliest appearances of Lithocampe elegantissima and perhaps Sethocapsa trachyostraca.

\section{Sphaerostylus lanceola Zone}

Base defined by the earliest morphotypic appearance of Sphaerostylus lanceola, which is approximately synchronous with the earliest appearances of Podobursa pantanellii, Acanthocircus dizonius, Cyrtocalpis operosa, and Theocorys antiqua.

The zone includes the latest occurrences of Haliodictya hojnosi, Eucyrtidium ptyctum, and Podobursa pantanellii. 
Figure 1 shows the approximate relationships between species ranges and zonal boundaries-for details, the reader should refer to Table 1. Also shown on Figure 1 are approximate equivalences between zones and stages. Again the reader is referred to Table 1 and the list of sample localities (with ages) for indications of the uncertainties involved.

It is not yet possible to make a comprehensive correlation between this zonation and those proposed by Foreman, Moore, and Pessagno, but the following few levels seem to be equivalent.

The boundary between Foreman's (1973b) Sethocapsa cetia assemblage and her $S$. trachyostraca assemblage is within our Staurosphaera septemporata Zone.

Although we have used a number of the samples examined by Moore (1973), we have not been able to correlate his zones satisfactorily with ours. Three points of approximate correspondence are that of Moore's R K 2/R K 3 boundary with the base of our Staurosphaera septemporata Zone, of his RK4/RK5 boundary with a level within our Dictyomitra veneta Zone, and of his RK6/RK7 boundary with a level within our $A r$ tostrobium urna Zone.

Correlation with Pessagno's (in press) zonation of the upper Cretaceous of California is even more difficult, the reason perhaps being that the North American radiolarian assemblages are from a different biogeographic province. The "level" that can most readily be compared is that represented by the upper limits of the forms recorded by Pessagno as Lithocampe (?) elegantissima, Phormocyrtis (?) veneta, and Dictyomitra (?) pseudomacrocephala, which occurs within his Rotaforma hessi Zone and within our Dictyomitra veneta Zone.

\section{SPECIES LIST}

The purpose of this list is to provide bibliographic references to the taxa mentioned in this chapter and to serve as a taxonomic index. Unless otherwise indicated, we have rather uncritically followed the generic assignments applied by earlier authors, since shortage of time has prevented our examining the relationships of type species of genera.

In order to facilitate scanning of this list, Cenozoic forms are asterisked.

Acanthocircus carinatus Foreman, 1973b, p. 260, pl. 5, fig. 1, 2.

We apply this name to all forms having only two strong spines arising rather close together, at the sides of the ring, whether or not there is a ridge between these spines. Thus, we here include the form recorded by Foreman (1973b, pl. 5, fig. 4, 5) as Acanthocircus sp. aff. Saturnalis variabilis Squinabol.

This chapter: Plate 2, Figures 1, 2.

Acanthocircus dizonius (Rüst)-Foreman, 1973b, p. 260, pl. 4, fig. 4, 5. We apply this name in a broader sense than do other authors, to include all saturnalin rings with a robust, thickened, three-lobed node at each lateral extremity of the ring. Thus we identify this form without the necessity for the preservation of less robust features (not observable in poorly preserved assemblages), while concomitantly sacrificing advantages gained from more precise species identifications. Our application of this name thus covers forms recorded as Saturnulus trizonalis Rüst $(1898$, p. 9, pl. 2, fig. 4; Foreman, 1973b, p. 261, pl. 4, fig. 6-8), Saturnalis dicranacanthos Squinabol (1914, p. 289, pl. 22, fig. 4-7, and pl. 23, fig. 8; Moore, 1973, p. 824, pl. 3, fig. 1, 3) and Saturnalis novalensis Squinabol
(1914, p. 297 , pl. 23 , fig. 7 ).

This chapter: Plate 2, Figures 3-5.

Afens liriodes Riedel and Sanfilippo, new genus and new species.

Siliceous structure resembling a stem surmounted by a calyx-like group of subparallel lamellae (or, rarely, a cup not separated into lamellae, as in Plate 13, Figure 14).

Dimensions (based on 12 specimens from Sample 146-15-5). Total length approximately $500 \mu$ (for unbroken specimens). Length of calyx-like structure $105-240 \mu$, its breadth $75-150 \mu$.

This evidently organic structure, of undetermined affinity, is not similar to any skeletal form known to the authors. It was recorded, unnamed, by Moore (1973, p. 830, pl. 13, fig. 1-3). The description of the species serves also as that of the genus. The generic name is an arbitrary combination of letters, and the specific name is the Greek adjective liriodes.

This chapter: Table 1; Figure 1; Plate 11, Figure 11; Plate 13, Figures 14-16.

Amphipyndax enesseffi Foreman,1966, p. 356, text-fig. 10, 11

This chapter: Table 1; Figure 1; Plate 10, Figures 12, 13.

Amphipyndax stocki (Campbell and Clark)-Foreman, 1968, p. 78, pl. 8 , fig. 12a-c.

This chapter: Site 250 text; Site 257 text; Tables 1, 2; Figure 1; Plate 11, Figures 1-3; Plate 15, Figure 11.

Archaeospongoprunum cortinaensis Pessagno, 1973, p. 60, pl. 9, fig. 4-6. We apply this name in a much wider sense than Pessagno, to include all forms with an ellipsoidal spongy shell and one or both spines spirally ridged. This is not to imply that fine specific distinctions are inappropriate in well-preserved assemblages.

This chapter: Tables 1, 2; Figure 1; Plate 1, Figures 9-11; Plate 14 , Figure 3.

Artostrobium urna Foreman,1971, p. 1677, pl. 4, fig. 1, 2.

The specimens recorded by Moore $(1973$, p. 826 , pl. 8, fig. 6) as Artostrobium tina Foreman seem to be closer to the holotype of $A$. urna.

This chapter: Table 1; Figure 1; Plate 11, Figures 4-6.

Bathropyramis Haeckel, 1881 , spp.

Under this name we record all forms with a very small cephalis, and conical thorax composed of continuous, straight longitudinal bars joined by transverse bars to form rectangular or rounded pores. An apical horn may or may not be present.

This chapter: Tables 1, 2; Figure 1; Plate 3, Figures 9-11; Plate 14, Figure 9.

Clathropyrgus bumastus Riedel and Sanfilippo, new species.

Similar in form to $C$. titthium, but with the terminal protuberance (and in some specimens also the lateral ones) inflatedhemispherical, closed, and with a very short terminal spine. The skeleton of this species also tends to be slightly larger than that of C. titthium.

Dimensions (based on 10 specimens from Sample 146-30-2). Total length $185-250 \mu$; breadth of abdomen without mammae $105-135 \mu$, with mammae $135-215 \mu$.

The specific name is derived from the Greek adjective boumastos.

C. bumastus, which appears to be an evolutionary offshoot of the longer-ranging $C$. titthium, exhibits the interesting tendency toward a symmetrically tethrahedral shape-the abdominal protuberances tending to envelop the thorax and cephalis and to be of the same size and form as the terminal protuberance. A similar tendency toward strict tetrahedral symmetry has been noted in Lithochytris vespertilio (Riedel and Sanfilippo, 1970, p. 529), though in that species the tetrahedron is oriented in the opposite sense, the cephalis and thorax forming one of the angles, and the base a flat side.

This chapter: Table 1; Figure 1; Plate 12, Figures 6-8.

Clathropyrgus titthium Riedel and Sanfilippo, new species.

Theoperids, gen. et sp. indet. Kling, 1971, pl. 8, fig. 7, 8 .

Theoperid, gen. et sp. indet. Foreman, 1971, p. 1676, pl. 3, fig. 3; 1973a, p. 430 , pl. 13, fig. 1. 
TABLE 1

Radiolarian Assemblages on which the Cretaceous Zonation is Based

\begin{tabular}{|c|c|c|c|c|c|c|c|c|c|c|c|}
\hline $\begin{array}{l}\text { Radiolarian } \\
\text { Zones }\end{array}$ & $\begin{array}{l}\text { DSDP } \\
\text { and other } \\
\text { samples } \\
\text { (Interval in cm) }\end{array}$ & 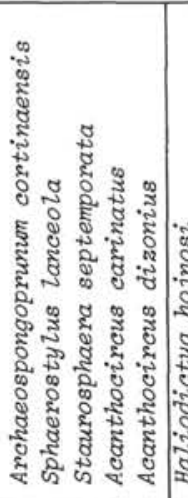 & 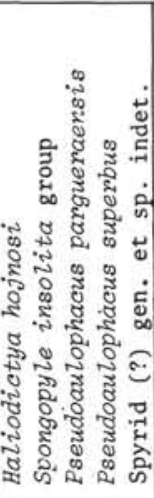 & 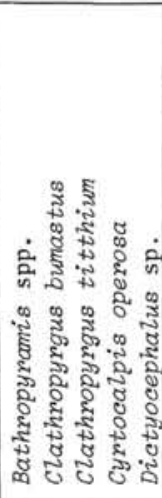 & 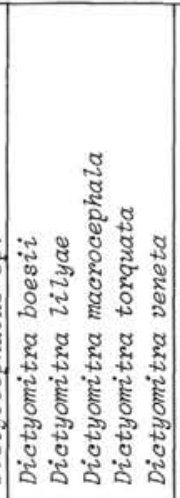 & 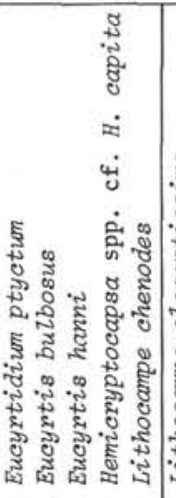 & 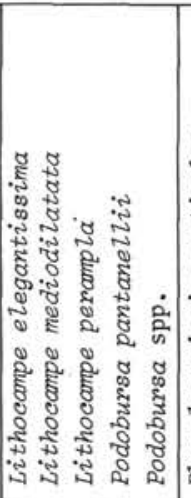 & 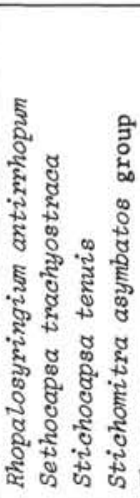 & 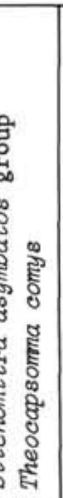 & 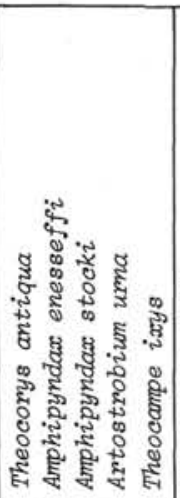 & 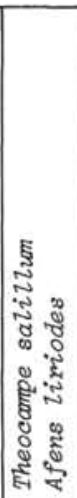 \\
\hline T. comys Zone & $146-15-5,15-25$ & $\mathrm{~F}-$ & 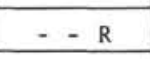 & $\ldots \ldots$ & - & & & $R$ & $R$ & $-+\mathrm{F}++$ & $R R$ \\
\hline $\begin{array}{l}\text { Amphipyndax } \\
\text { enesseffi zone }\end{array}$ & $\begin{array}{l}146-27-1,1-11 \\
164-11-1,128-130\end{array}$ & $\begin{array}{ll}R & \\
+- & \end{array}$ & $\begin{array}{l}? \mathrm{FF} \\
+\mathrm{RR}\end{array}$ & $\begin{array}{l}++\cdots x \\
+\cdots+-\cdots \\
\end{array}$ & $\begin{array}{l}\mathrm{F} \\
\mathrm{R}\end{array}$ & & & $\begin{array}{l}R \\
-\quad R \\
\end{array}$ & - & $\begin{array}{l}\mathrm{F} X+- \\
-\mathrm{F} R-{ }^{2}\end{array}$ & $\begin{array}{ll}R & R \\
R & -\end{array}$ \\
\hline $\begin{array}{l}\text { Artostrobivom } \\
\text { urnd Zone }\end{array}$ & $\begin{array}{l}\text { WRE } 67-42 \\
146-30-2, \quad 79-85 \\
164-16-1, \quad 141-143 \\
\text { WRTR } 57\end{array}$ & \begin{tabular}{ll|l}
$R-$ & & \\
$R-$ & - & $X$ \\
+- & - & - \\
$R-\cdots$ & - & \\
\end{tabular} & 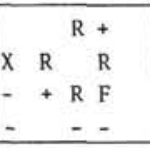 & 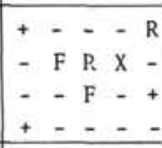 & 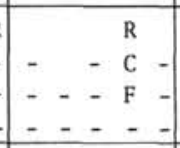 & & 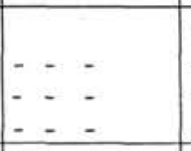 & $\begin{array}{lll} & & \\
\therefore & & R \\
- & F \\
\end{array}$ & $\begin{array}{l}- \\
- \\
- \\
-\end{array}$ & $\begin{array}{|llll|}\because- & F & R & - \\
X- & R & F & X \\
-- & R & F & - \\
R & -R & F & - \\
\end{array}$ & $\begin{array}{l}R \\
F+ \\
F- \\
-- \\
\end{array}$ \\
\hline \multirow[t]{2}{*}{$\begin{array}{l}\text { Dictyomitra } \\
\text { veneta Zone }\end{array}$} & $\begin{array}{l}261-12, \text { CC } \\
\text { Gearle CC-19 } \\
\text { Gearle CC-16 } \\
167-60-2, \quad 128-130 \\
167-61-1, \quad 132-134 \\
\end{array}$ & 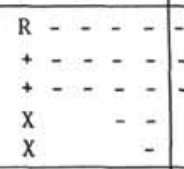 & 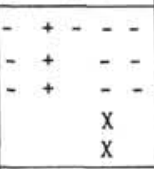 & 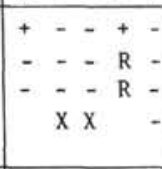 & $\left|\begin{array}{rrrr}- & ? & - & - \\
- & - & - \\
- & ? & - & - \\
& R & - \\
& R \\
R & + & +\end{array}\right|$ & 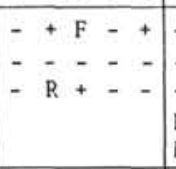 & \begin{tabular}{llll}
$\cdots$ & $\cdots$ & $\cdots$ \\
\hdashline & $\cdots$ & - & $\cdots$ \\
$R$ & & & \\
$R$ & & \\
\end{tabular} & $\begin{array}{l}\cdots \\
\because \cdots F \\
-\quad-F\end{array}$ & F & 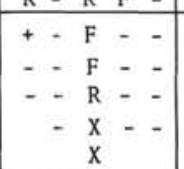 & $\begin{array}{l}-- \\
-- \\
--\end{array}$ \\
\hline & $\begin{array}{l}167-61-2,104-106 \\
167-62-2, \quad 136-138 \\
\text { Beets R60-161 } \\
167-64-5, \quad 15-17 \\
\end{array}$ & 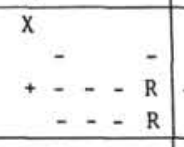 & $\begin{array}{r}x \\
-\quad-\quad- \\
x \\
\end{array}$ & $\therefore$ & 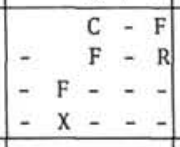 & $\begin{array}{c}-\mathrm{RR}- \\
-\end{array}$ & \begin{tabular}{|l|}
$R$ \\
$R--$ \\
-- \\
-
\end{tabular} & $\begin{array}{ll}-X \\
- & -R R \\
- & R \\
\end{array}$ & & $\begin{array}{r}\mathrm{X}- \\
\mathrm{F}-\mathrm{R}- \\
\end{array}$ & $\cdots$ \\
\hline \multirow{2}{*}{$\begin{array}{l}\text { Stichocapsa } \\
\text { tenuis Zone }\end{array}$} & $\begin{array}{l}249-24-1,106-108 \\
\text { Rotti } 150 \\
167-67-3,101-103 \\
167-67-4,55-56 \\
167-69-3,36-38 \\
\end{array}$ & \begin{tabular}{rrrr|} 
& $R$ & - & - \\
$-F$ & - & $R$ \\
$C$ & + & $R$ & $F$ \\
$F$ & $+R$ & $R$ \\
$R$ & $-R$ & $R$ \\
\end{tabular} & $\begin{array}{rr}\mathrm{R} & \cdots \\
-+ & - \\
& - \\
& \\
& \\
\end{array}$ & 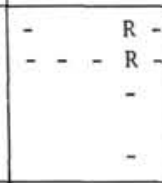 & \begin{tabular}{|llll}
- & $R$ & - & - \\
+ & $R$ & - & - \\
$R$ & $X$ & - & - \\
$R$ & $X$ & & \\
$R$
\end{tabular} & 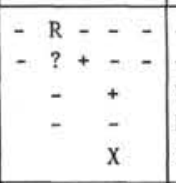 & \begin{tabular}{l}
$-\cdots-\cdots$ \\
\hdashline$-\cdots$ \\
$R-+$ \\
$R+-$ \\
$R+$
\end{tabular} & \begin{tabular}{c}
$-\cdots$ \\
\hdashline$-R$ \\
$-R$ \\
+
\end{tabular} & \begin{tabular}{ll|}
$R-$ & \\
+ & -
\end{tabular} & $\begin{array}{l}C=R- \\
R-R= \\
- \\
-\end{array}$ & -- \\
\hline & $\begin{array}{l}167-70-2, \quad 34-40 \\
167-70-4, \quad 140-142 \\
167-72-2,48-50 \\
167-72, \mathrm{CC} \\
\end{array}$ & $\begin{array}{llll}R & - & R & R \\
R & R & R & R \\
R & F & R \\
R & R & R & R \\
R & R & R\end{array}$ & $\mathrm{x}$ & - & $\begin{array}{ll}+ & \mathrm{X} \\
+ & \\
\mathrm{F} & \mathrm{X} \\
\end{array}$ & $\mathrm{x}$ & $\mathrm{R}+$ & $\begin{array}{ll}+R \\
R & R \\
R \\
R \\
R\end{array}$ & & - & \\
\hline $\begin{array}{l}\text { Staurosphaera } \\
\text { septemporata } \\
\text { Zone }\end{array}$ & $\begin{array}{l}167-73-2,30-32 \\
167-74-2,74-76 \\
167-76-2,65-67 \\
99 A-8-1,112-116\end{array}$ & 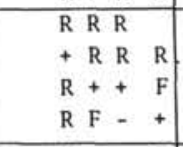 & -+ & + & $\begin{array}{ll}R & \\
R & X \\
R & X \\
- & - \\
\end{array}$ & $\begin{array}{r}R \\
R \\
-\quad R \\
\end{array}$ & $\begin{array}{ll}R & \\
R & R \\
R & + \\
-+ & + \\
-+ & \\
\end{array}$ & $\begin{array}{l}\mathrm{R}- \\
-= \\
\mathrm{R}- \\
-\end{array}$ & & - & - \\
\hline $\begin{array}{l}\text { Sphaerostylus } \\
\text { lanceola Zone }\end{array}$ & $\begin{array}{l}167-88, \text { CC } \\
167-93-2,22-24 \\
167-94-2,40-42 \\
\text { Pt. Sal } \\
\end{array}$ & $\begin{array}{lll}\mathrm{F}-\ldots & \mathrm{R} \\
\mathrm{C}-\mathrm{F} & \mathrm{F} \\
\mathrm{F} & - \\
\mathrm{F}-+ & + \\
\end{array}$ & \begin{tabular}{|l|}
$x$ \\
$x$ \\
$x$ \\
$R+$ \\
\end{tabular} & + & $\begin{array}{ll}R & X \\
& X \\
R & X \\
R & - \\
\end{array}$ & 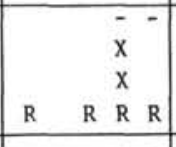 & \begin{tabular}{|llll}
- & + & & \\
- & & + & - \\
+ & + & $X$ \\
- & F & F & R \\
\end{tabular} & $=$ & & $+\cdots$ & \\
\hline $\begin{array}{l}\text { Unzoned } \\
\text { Late Jurassic }\end{array}$ & WRE $67-74$ & $\cdots+$ & R R & - & +- & $R-++R$ & $+F-R$ & $? \quad \mathrm{R}$ & & $\cdots$ & - \\
\hline
\end{tabular}




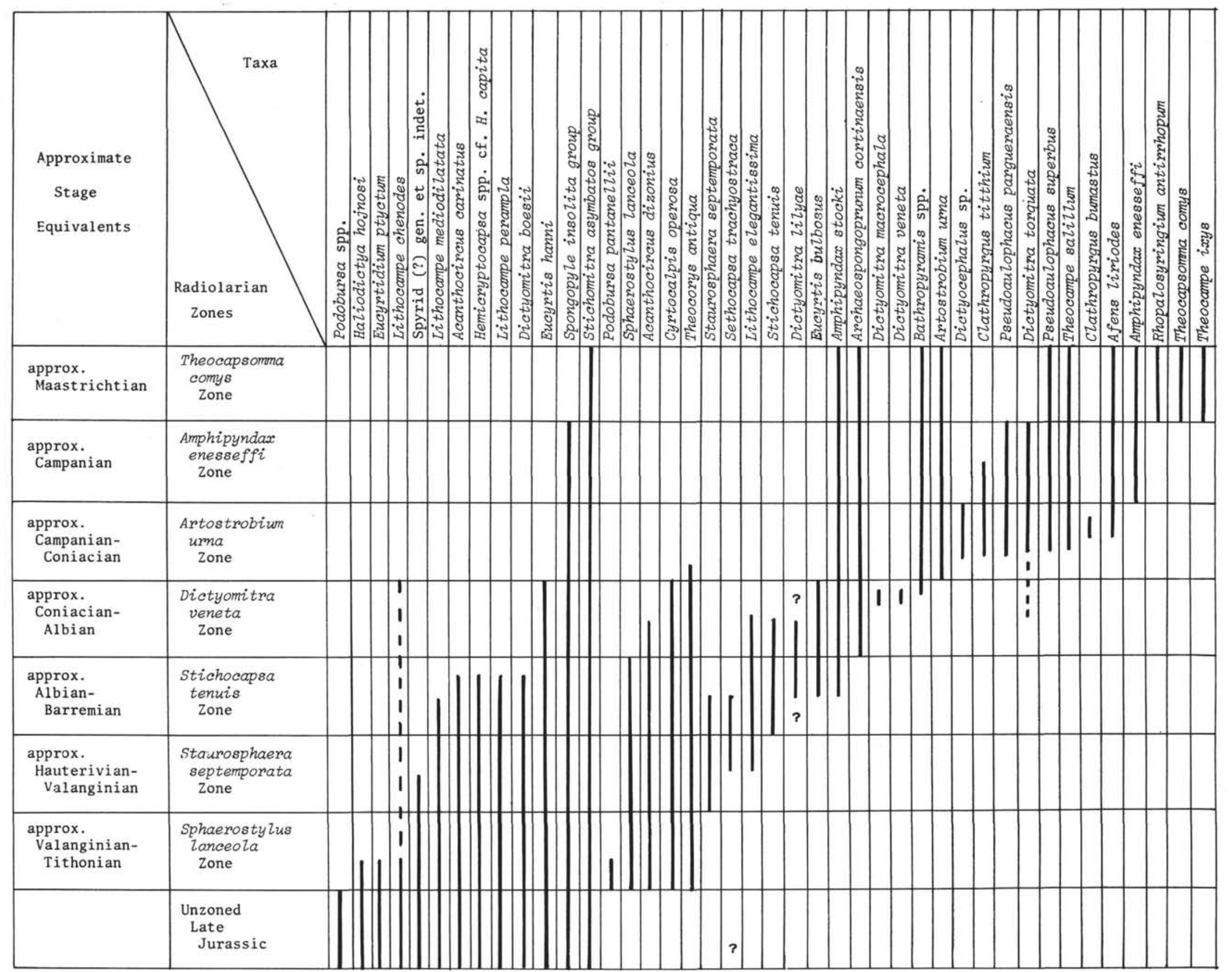

Figure 1. Generalized ranges of Cretaceous radiolarians. For details, see Table 1. 
TABLE 2

Cretaceous Radiolarians at Sites 256 and 258

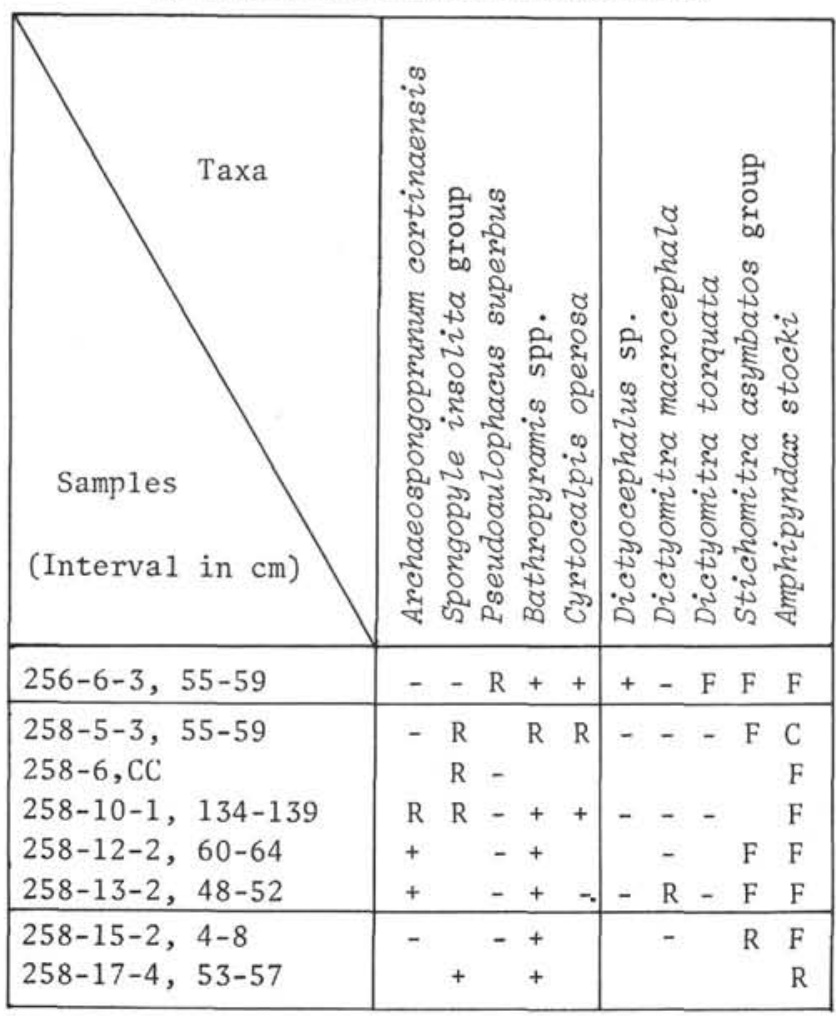

Artopilium sp. A Moore, 1973, p. 830, pl. 11, fig. 7.

Gen. et sp. indet. Riedel and Sanfilippo, 1973, pl. 4, fig. 15.

Cephalis very small, in some specimens enclosed in the base of a short relatively robust horn. Thorax small, inflated-hemispherical. Abdomen inflated-campanulate, with three large gates proximally, of about the same size as its mouth or slightly smaller, surmounted by conical protuberances similar in form to one that covers the mouth. In some specimens the protuberances are closed and bear terminal spines. Pores circular to subcircular, irregularly arranged. Dimensions (based on 20 specimens from DSDP Samples 164-16. $1,141-143 \mathrm{~cm}$ and $146-30-2,79-85 \mathrm{~cm}$ ). Total length $125-200 \mu$; breadth of abdomen without mammae $70-125 \mu$, with mammae $110-170 \mu$.

This species differs from $C$. bumastus as indicated in the description of that species. We assign it to Clathropyrgus since our species conforms approximately to the original diagnosis of this genus by Haeckel (1881), and resembles one species (Artopilium trifenestra) assigned to it by him (1887). The specific name is the Greek noun titthion, used in apposition.

This chapter: Table 1; Figure 1; Plate 3, Figure 12; Plate 12, Figures 9-12.

*Cyclampterium (?) milowi Riedel and Sanfilippo -Sanfilippo and Riedel in Sanfilippo et al., 1973, p. 220, pl. 4, fig. 12-14. This chapter: Site 257 text.

Cyrtocalpis operosa Tan Sin Hok, 1927, p. 40, pl. 7, fig. 27. This species, with pores more regularly arranged than Archicorys turgida Tan Sin Hok (1927, p. 40, pl. 7, fig. 25, 26) has a very small cephalis which is merged with the upper part of the thorax and was therefore overlooked by Tan Sin Hok.

This chapter: Site 257 text; Tables 1, 2; Figure 1; Plate 4, Figures 1-3; Plate 14, Figure 10.

Dictyocephalus sp. Pessagno,1963, p. 204, pl. 1, fig. 2; pl. 4, fig. 4; textfig. 3 .

This form, with large hemispherical cephalis and inflated, longitudinally ribbed thorax, occurs very rarely in some of our Late Cretaceous assemblages.
This chapter: Tables 1, 2; Figure 1; Plate 4, Figure 4; Plate 14, Figure 1.

Dictyomitra boesii Parona, 1890, p. 41, pl. 6, fig. 9; Moore, 1973, p. 828, pl. 4, fig. 7-9 (as Lithocampe ananassa Rüst).

The dimensions of the form in our material are less than those given in the original description of Lithocampe ananassa, and therefore assignment to $D$. boesii seems more appropriate.

This chapter: Table 1; Figure 1; Plate 4, Figures 5, 6.

Dictyomitra lilyae Tan Sin Hok, 1927, p. 55, pl. 10, fig. 83.

The forms recorded under this name conform with Tan Sin Hok's illustration, and in addition the following characters are noted. Segments beyond about the fourth tend to have their greatest width in the upper half of the segment. Characteristically, the shell surface is ornamented by pronounced longitudinal costae which fork near the bottom of each segment, where a single row of oblique pores is situated.

This chapter: Table 1; Figure 1; Plate 4, Figures 7-9; Plate 12, Figure 13.

Dictyomitra macrocephala Squinabol-Moore, 1973, p. 829, pl. 9, fig. $8,9$.

This chapter: Tables 1, 2; Figure 1; Plate 4, Figures 10, 11; Plate 14, Figure 11.

Dictyomitra sp. cf. D. regina (Campbell and Clark)-Foreman, 1968, p. 68 , pl. 8 , fig. 5 .

The Cretaceous assemblages from Leg 26 include forms (Plate 15 , Figures 1-3) with cephalo-thoracic structure similar to that illustrated by Foreman, but with less-regular costae and longitudinal pore rows. We have not tabulated occurrences of this form.

Dictyomitra torquata Foreman,1971, p. 1676, pl. 3, fig. 4.

We use this name in a much broader sense than Foreman, admitting also specimens in which no feet are preserved and in which the longitudinally ribbed segments are not each markedly expanded distally. The principal criterion that we have used for its recognition is expansion of the fourth (occasionally third or fifth) segment, and thus the majority of our specimens are closer to her co-occurring Dictyomitra sp. (Foreman, 1971, p. 1677, pl. 3, fig. 5) and Dictyomitra sp cf. D. torquata Foreman of Moore (1973, p. 829 , pl. 9, fig. 1-4).

This chapter: Tables 1, 2; Figure 1; Plate 5, Figures 1-4; Plate 14, Figure 2.

Dictyomitra veneta (Squinabol), 1903, p. 134, pl. 9, fig. 30)-Petrushevskaya and Kozlova, 1972, p. 550, pl. 2, fig. 2.

This chapter: Table 1; Figure 1; Plate 5, Figures 5, 6.

Eucyrtidium ptyctum Riedel and Sanfilippo, new species.

Form usually of three segments, with only a trace of a fourth preserved. Cephalis subspherical, in some specimens with an apical horn and thorax inflated-hemispherical-these two segments poreless, hyaline. Third segment inflated-annular, usually with broad longitudinal plicae, hyaline, poreless, or with irregularly arranged small pores in the distal quarter. Some specimens have fragments of delicate shell wall indicating the presence of a fourth segment.

Measurements (based on 20 specimens from WRE 67-74 and Pt. Sal). Total length of three segments (excluding horn) $75-110 \mu$; maximum breadth $65-90 \mu$.

This species is distinguished by the third segment being broadly costate, and/or having small pores grouped in its distal part. The specific name is derived from the Greek adjective ptyctos.

This chapter: Table 1; Figure 1; Plate 5, Figure 7; Plate 12, Figures 14, 15.

Eurcyrtis bulbosus Renz, in preparation, pl. 7, fig. 26-29; pl. 12, fig. 15. The conical portion of the shell, above the inflated segment, comprises approximately four to six segments.

This chapter: Table 1; Figure 1; Plate 5, Figure 8. 
Eucyrtis hanni (Tan Sin Hok) - Renz, in preparation pl. 7, fig. 21-25; pl. 12, fig. 16.

We have examined the radiolarian assemblage in Tan's (1927) sample 149 and find specimens with surface spines variously developed as in Renz's and our illustrations, but none with a tuberculate surface as in Tan's illustration.

This chapter: Table 1; Figure 1; Plate 5, Figures 9-14; Plate 12, Figures 16-18.

Hagiastrin ef. Staurolonchidium tuberosum Rüst, 1898, p. 10, pl. 2, fig. 7.

Spherical central body consisting of two internal shells closely spaced, and a more widely separated outer shell which is puckered, thorny, subspherical, with pores of very variable size. The concentric shells are connected by rather numerous bars in addition to those continuous with the arms. From the surface of the innermost shell arise four or six narrow, cylindroconical arms (in one plane or in cubic axes, respectively) of hagiastrin structure, terminating in bladed spines.

Measurements (based on 15 specimens from DSDP Samples 258-7-1, 105-107 cm; 258-7-2, 55-60 cm; and 258-9-1, 50-55 cm). Diameter of outermost subspherical shell $90-255 \mu$. Length of arm (including spine) $70-415 \mu$.

Our specimens are only hesitantly compared with Rüst's species, but are almost certainly closely related to the form illustrated by Petrushevskaya and Kozlova (1972, pl. 4, fig. 8) as an unidentified spongodiscid.

This noteworthy form was found only in Cretaceous assemblages of Leg 26 (Plate 14, Figures 5-8), and it is therefore not included in the tables.

Haliodictya hojnosi Riedel and Sanfilippo,new species.

Four-armed to approximately square form with the central body composed, at least in part, of very small, regular, square meshes. Some small specimens consist only of the finely-squared central body with very short bladed spines at the corners, some have an irregularly spongy zone surrounding the finely-squared central body, and in still others the irregularly spongy material is extended as four arms passing into the bladed spines. The finely-squared central structure may be covered in some specimens by irregularly spongy material.

Dimensions (based on 12 specimens from WRE 67-74 and Pt. Sal). Minimum diameter of skeleton $90-125 \mu$, its maximum diameter (including arms and spines) $160-275 \mu$.

This species is distinguished from other, superficially similar forms by the regularly and finely squared central body. It is assigned to Hojnos' genus with some reservations, since the type species ( $H$. loerentheyi Hojnos, 1916, p. 349, pl. 3, fig. 10) appears to have concentric structure in the central body. Spongolonche inaequispinata Parona (1890, p. 32, pl. 4 , fig. 7) has much larger spines, but may be related. Another possibly related form is Staurosphaera sedecimporata elegans Wisniowski $(1889$, p. 683, pl. 13, fig. 48), in which the squared meshes are coarser.

This chapter: Table 1; Figure 1; Plate 2, Figure 6; Plate 12, Figures 2, 3 .

Hemicryptocapsa spp. cf. H. capita Tan Sin Hok, 1927, p. 50, pl. 9, fig. 67.

Under this name we record several species with small cephalis and thorax, inflated subspherical abdomen, and an invertedconical cap over the mouth. In some specimens, the abdominal pores are regular in size and arrangement as in $H$. capita, but in others they are irregular, and the shell surface is irregularly ridged. There are also differences in shell size and wall thickness.

This chapter: Table 1; Figure 1; Plate 6, Figures 1-4.

Lithocampe chenodes Renz, in preparation, pl. 7, fig. 30; pl. 12, fig. 14. Under this name we include also specimens with a nodose rather than a spiny surface. Small fragments are recognizable on the basis of the characteristic combination of small, rounded pores (approximately four across the width of a segment) and a superimposed coarse network of irregular ridges.

This chapter: Table 1; Figure 1; Plate 6, Figures 5-7; Plate 13, Figure 1.
Lithocampe elegantissima Cita, 1964, p. 148, pl. 12, fig. 2, 3; Moore, 1973 , p. 826 , pl. 3, fig. 4-6 (as Sethamphora pulchra).

In this species, the narrow, upper conical portion of three (often indistinguishable) segments is separated by an abrupt change in contour from the broad, campanulate, lowest segment. The entire shell surface is prominently longitudinally ribbed. Our material contains other forms which are rather similar, but are not recorded under this name-some have a less-abrupt change in external contour (Plate 13, Figure 5) and might appropriately be identified as Sethamphora pulchra Squinabol (1904, p. 213, pl. 5, fig. 8).

This chapter: Table 1; Figure 1; Plate 6, Figures 8-10; Plate 13, Figures 2-4.

Lithocampe mediodilatata Rüst-Moore, 1973, p. 828, pl. 2, fig. 5, 6.

We have used this name for all fragments of large, medially or terminally swollen stichocyrtids in which the inflated portion is composed of many narrow segments, each with two rows of alternating triangular pores, those of each upper row with their apices directed downward and those of each lower row with apices directed upward. Thus small fragments of the shell can be recognized.

This chapter: Table 1; Figure 1; Plate 7, Figures 1-4.

Lithocampe perampla Rüst, 1885, p. 315, pl. 39, fig. 11.

We apply this name to a large form with usually approximately seven segments, which are inflated-annular, markedly but gradually increasing in size downward, and with a thick spongy wall showing little if any superficial indentation between segments.

Moore (1973, p. 827, pl. 5, fig. 2) has included this form, together with specimens in which the terminal segment is much more distinct and inflated, under the name Stichocapsa rotunda Hinde.

This chapter: Table 1; Figure 1; Plate 8, Figures 1-4.

${ }^{*}$ Lophocyrtis biaurita (Ehrenberg)-Cita, Nigrini, and Gartner, 1970, p. 404 , pl. 2 , fig. I, J, K.

This chapter: Site 253 text.

*Lychnocanoma bellum (Clark and Campbell) -Foreman, 1973a, p. 437 , pl. 1 , fig. 17 ; pl. 11, fig. 9.

This chapter: Site 253 text.

*Ommatartus antepenultimus Riedel and Sanfilippo, 1970, p. 521, pl. 14 , fig. 4.

This chapter: Site 252 text.

*Ommatartus avitus(Riedel)-Riedel and Sanfilippo, 1971, p. 1588, pl. 4 , fig. 6 .

This chapter: Site 252 text.

*Ommatartus penultimus(Riedel)—Riedel and Funnell, 1964, p. 311. This chapter: Site 252 text.

*Phormocyrtis striata striata Brandt-Foreman, 1973a, p. 438, pl. 7, fig. $5,6,9$.

This chapter: Site 253 text.

*Phormostichoartus corona Haeckel-Riedel and Sanfilippo, 1971, p. 1600 , pl. 1I, fig. 13-15; pl. 2J, fig. 1-5.

This chapter: Site 252 text.

Podobursa Wisniowski (1889, p. 686) amend. Foreman (1973b) spp. Under this name we record all forms conforming to Foreman's emended definition of this genus and, in addition, some specimens with five segments.

Forms similar to this genus but lacking lateral spines (Plate 9, Figures 1, 2) co-occur with Podobursa spp. and also range higher (to at least Core 167-67).

This chapter: Table 1; Figure 1; Plate 13, Figure 7.

Podobursa pantanellii (Parona,1890, p. 35, pl. 5, fig. 8).

This species is distinguished from others in the genus by the lateral spines being tri- or multi-furcate terminally. In some specimens the apical horn and basal tube are also "clove-like" terminally.

The lack of a conical upper portion in the specimen figured by Parona is believed to be due to the oblique orientation of his thin- 
section. The termination of the spine illustrated by Parona appears rather different from our specimens, but this also may be a result of the orientation of the thin-section.

It seems likely that this species is the same as that figured as indeterminatum by Heitzer (1930, pl. 27, fig. 7).

This chapter: Table 1; Figure 1; Plate 8, Figure 5; Plate 13, Figure 6.

*Podocyrtis papalis Ehrenberg-Riedel and Sanfilippo, 1970, p. 533, pl. 11, fig. 1 .

This chapter: Site 253 text.

Pseudoaulophacus pargueraensis Pessagno,1963, p. 204, pl. 2, fig. 4, 7; pl. 6 , fig. 4,5 .

This chapter: Table 1; Figure 1; Plate 2, Figures 12-14.

Pseudoaulophacus superbus (Squinabol) -Foreman, 1971, p. 1675, pl. 2 , fig. 5 .

We use this name in a broad sense, for all coarse-pored pseudoaulophacids with a triangular outline, whether or not spines are present. Pessagno (1972) would evidently separate these into several species of Alievium, in well-preserved assemblages. $1-3$

This chapter: Site 257 text; Tables 1, 2; Figure 1; Plate 3, Figures

*Pterocorys hertwigii (Haeckel) - Petrushevskaya, 1972, fig. 1 (10).

This chapter: Site 252 text.

Rhopalosyringium antirrhopum Riedel and Sanfilippo, new species.

Three-segmented form with large cephalis, inflated thorax, and subcylindrical abdomen swollen distally or medially as if to counterbalance the upper section of the skeleton. The cephalis bears a long bladed horn, and in some specimens the abdomen is drawn out into a narrow terminal tube. The pores are subcircular to circular, rather larger on the thorax than on the abdomen.

Dimensions (based on 15 specimens from DSDP Sample 146-15$5,15-25 \mathrm{~cm}$ ). Total length (excluding horn) $160-330 \mu$. Maximum breadth $55-115 \mu$.

This form co-occurs with more numerous specimens of one or more somewhat smaller species in which the abdomen is not swollen, and which has been recorded as Rhopalosyringium magnificum, $R$. sparnon, $R$. elasson, or $R$. colpodes (Campbell and Clark, 1944, p. 30, pl. 7, fig. 16, 17; Foreman, 1968, p. 55-57, pl. 6, fig. 5-8; Petrushevskaya and Kozlova, 1972, p. 536-537, pl. 7, fig. 12-17).

The specific name is derived from the Greek adjective antirrhopos.

This chapter: Table 1; Figure 1; Plate 9, Figure 3, Plate 13, Figures 8-10.

Sethocapsa trachyostraca Foreman, 1973b, p. 268, pl. 12, fig. 4.

This chapter: Table 1; Figure 1; Plate 9, Figures 5-7.

Solenotryma Foreman (1968, p. 33) spp.

Apparently closely related to or conspecific with the type species of this genus ( $S$. dacryodes Foreman, 1968, p. 33, pl. 4, fig. 8 ) is a three-segmented form lacking a terminal tube, and occurring in the Leg 26 Cretaceous assemblages (Plate 15, Figure 4).

Rather similar forms, but with more segments, occur at other localities (Plate 9, Figures 9-11; Plate 13, Figure 11). We have not tabulated the occurrences of members of this genus.

This chapter: Plate 9, Figures 9-11; Plate 13, Figure 11; Plate 15, Figure 4.

Sphaerostylus Ianceola (Parona)-Foreman, 1973b, p. 258, pl. 1, fig. 711.

This species is recorded by Moore (1973, p. 823, pl. 2, fig. 1) as Stylatractus ovatus Hinde.

Sphaerostylus lanceola is evidently preceded by a form with a narrower cortical shell and relatively larger, robust spines (Plate I, Figures 4, 5; Plate 12, Figure 1), which may be related to or identical with Xiphosphaera tredecimporata Rüst (1885, p. 288, pl. 27, fig. 15) and/or Stylosphaera resistens $\mathrm{R}$ üst (1885, p. 291, pl. 28 , fig. 15),

This chapter: Table 1; Figure 1; Plate 1, Figures 1-3.
Spongopyle insolita Kozlova group - Kozlova and Gorbovets, 1966, p. 91, pl. 4, fig. $11 \mathrm{a}, \mathrm{b}$.

Under this name we record all forms consisting of a spongy or finely-chambered disc with an enclosed or adjoining hollow cone constituting a major part of the skeleton.

This chapter: Tables 1, 2; Figure 1; Plate 2, Figures 7-11; Plate 14, Figure 4.

Spyrid (?) gen. et sp. indet.

The assemblage from Pt. Sal (and some others probably near the Jurassic-Cretaceous boundary) contains a form that may be either a spyrid or a small, simple plagoniid, which we illustrate but do not tabulate. The cephalis is inflated-hemispherical, sparsely pored. There are six collar pores, separated by the median bar, vertical, dorsal, and primary and secondary lateral bars. The apical bar extends as a columella within the cephalic cavity, and in some specimens extends beyond the shell wall as a spine. Divergent, bladed feet arise from the dorsal and primary lateral bars. There is no very distinct ring connecting the apical and vertical bars.

This chapter: Table 1; Figure 1; Plate 3, Figures 4-8; Plate 12, Figure 5 .

Staurosphaera septemporata Parona -Moore, 1973, pl. 2, fig. 2; Foreman, 1973b, p. 259, pl. 3, fig. 4.

As is indicated by Foreman, specimens assigned to this species have less regular spines than indicated in Parona's description. We use the same generic assignment as do Moore and Foreman, though it is clearly inappropriate to assign to separate genera two species so closely related as this and Sphaerostylus lanceola.

This chapter: Table 1; Figure 1; Plate 1, Figures 6-8.

Stichocapsa tenuis Rüst, 1885 , p. 318 , pl. 41 , fig. $13,14$. It is not clear how Eucyrtis (?) zhamoidai Foreman (1973b, p. 264 , pl. 10 , fig. 9,10 ; pl. 16, fig. 1,2 ) is to be distinguished from this species.

This chapter: Table 1; Figure 1; Plate 9, Figures 12-14.

*Stichocorys delmontensis (Campbell and Clark) -Sanfilippo and Riedel, 1970, p. 451, pl. 1, fig. 9.

This chapter: Site 252 text.

*Stichocorys peregrina (Riedel)-Sanfilippo and Riedel, 1970, p. 451, pl. 1, fig. 10.

This chapter: Site 252 text.

Stichomitra asymbatos Foreman group -Foreman, 1968, p. 73, pl. 8, fig. 10a-c.

In this group we include stichocyrtids with a relatively large cephalis and apical horn, thorax very sparsely porous, and subsequent segments having many closely-spaced, small pores and rough to nodose surface.

This chapter: Site 257 text; Tables 1, 2; Figure 1; Plate 10, Figures 1-7; Plate 15, Figure 5.

Theocampe ixys Riedel and Sanfilippo, new species.

Three-segmented form with distinct collar and lumbar strictures and a long, constricted, poreless peristome. Thorax truncateconical, widest distally where the wall tends to be thicker. Abdomen approximately twice as long as, and not much wider than, the thorax, widest just above the peristome where the wall again tends to be thicker. Abdominal pores small, sparse, in about 3 or 4 transverse rows.

Dimensions (based on 12 specimens from DSDP Samples 14627-1, 1-11 cm; 170-9, CC and WRE 67-42). Total length 115-130 maximum breadth $65-80 \mu$.

This species differs from $T$. salillum in the pronounced distal widening of the thorax and abdomen, associated with thickening of the shell wall. The name is the Greek noun ixys, used in apposition.

This chapter: Table 1; Figure 1; Plate 11, Figure 7; Plate 13, Figures 12, 13

Theocampe salillum Foreman, 1971, p. 1678, pl. 4, fig. 5. This chapter: Table 1; Figure 1; Plate 11, Figures 8-10. 
*Theocampe urceolus (Haeckel)-Foreman, 1973a, p. 432, pl. 8, fig. 14-17; pl. 9, fig. 6, 7.

This chapter: Site 253 text.

Theocapsomma comys Foreman, 1968, p. 29, pl. 4, fig. 2a-c.

This species may be closely related to, or identical with, Dictyocephalus legumen Campbell and Clark (1944, p. 28, pl. 7, fig. 1, 1214). Our specimens usually have a wide open, ragged termination, as if incomplete.

This chapter: Table 1; Figure 1; Plate 10, Figure 8.

*Theocorys anapographa Riedel and Sanfilippo-Foreman, 1973a, p. 440 , pl. 5, fig. 9, 10.

This chapter: Site 253 text.

Theocorys antiqua Squinabol, 1903, p. 135, pl. 8, fig. 25; Renz, in preparation, pl. 6, fig. 4-7, pl. 11, fig. 4 (as Theocorys sp. aff. $T$. antiqua).

This three- or four-segmented form has a small thorax, and the last segment large, with small (usually longitudinally aligned) pores and very constricted mouth.

This chapter: Table 1; Figure 1; Plate 10, Figures 9-11.

*Thyrsocyrtis tricantha (Ehrenberg) -Foreman, 1973a, p. 442, pl. 12, fig. 9-11.

This chapter: Site 257 text.

\section{ACKNOWLEDGMENTS}

This work would not have been possible without the cooperation of a number of colleagues who provided Mesozoic radiolarian samples, or guidance in the field during collecting trips, or evaluation of calcareous microfossils occurring together with the radiolarians. The backbone of the Cretaceous zonation is a series of preparations from DSDP Site 167 generously provided by T. C. Moore, Jr. on the completion of his work for the Leg 17 Initial Report, and G. W. Renz provided preparations from DSDP Site 261. Other samples or collecting guidance were kindly provided by Th. B. Roep, D. J. Beets, D. J. Belford, P. G. Quilty, C. A. Hopson, D. E. Karig, H. A. Brouwer, H. J. de Wijs, D. Herm, G. Ruggieri, F. Barbieri, and J. B. Saunders. D. Bukry and P. H. Roth evaluated calcareous nannofossil assemblages in critical samples of uncertain age. We are grateful also to H. P. Foreman, G. W. Renz, and E. A. Pessagno, Jr., who provided copies of typescripts of papers on Mesozoic radiolarians, prior to their publication.

Financial support for this study was provided partly by NSF Grant No. GA-31284X, and partly by the University of California. P. S. Doyle, aboard Glomar Challenger during DSDP Leg 26, prepared the radiolarians on which part of this work was based. The onerous tasks of typing and proofreading were competently performed by M. A. Hanger and M. A. Neely, and M. J. Westberg assisted in many aspects of the work.

\section{REFERENCES}

Bolli, H. M., 1957. The genera Praeglobotruncana, Rotalipora, Globotruncana and Abathomphalus in the upper Cretaceous of Trinidad, B.W.I., U.S. Natl. Mus. Bull., p. 5160 , pls. 12-14.

Bukry, D., 1972. Coccolith stratigraphy, Leg 11, Deep Sea Drilling Project. In Hollister, C. D., Ewing, J. I., et al., Initial Reports of the Deep Sea Drilling Project, Volume 11: Washington (U.S. Government Printing Office), p. 475482.

Campbell, A. S. and Clark, B. L., 1944. Radiolaria from upper Cretaceous of middle California: Geol. Soc. Amer. Spec Paper 57, p. 1-61.
Cita, M. B. S., 1964. Ricerche micropaleontologiche e stratigrafiche sui sedimenti pelagici del Giurassico superiore e del Cretaceo inferiore nella catena del Monte Baldo: Riv. Ital. Paleontol. Strat., Mem. 10, p. 1-182.

Cita, M. B. S., Nigrini, C., and Gartner, S., 1970. Biostratigraphy. In Peterson, M. N. A., et al., Initial Reports of the Deep Sea Drilling Project, Volume 2: Washington (U.S. Government Printing Office), p. 391411.

Condon, M. A., Johnstone, D., Prichard, C. E., and Johnstone, M. H., 1956. The Giralia and Marrilla Anticlines, North West Division, Western Australia: Australia Bur. Min. Res., Geol. Geophys. Bull. 25, p. 1-86.

Foreman, H. P., 1966. Two Cretaceous radiolarian genera: Micropaleontology, v. 12, no. 3, p. 355-359.

1968. Upper Maestrichtian Radiolaria of California: Spec. Papers Palaeontol., (Palaeontol. Assoc., London), no. 3 , p. $1-82$.

1971. Cretaceous Radiolaria. In Winterer, E. L., Riedel, W. R., et al., Initial Reports of the Deep Sea Drilling Project, Volume 7: Washington (U.S. Government Printing Office), p. 1673-1693.

1973a. Radiolaria of Leg 10 with systematics and ranges for the families Amphipyndacidae, Artostrobiidae, and Theoperidae. In Worzel, J. L., Bryant, W., et al., Initial Reports of the Deep Sea Drilling Project, Volume 10: Washington (U.S. Government Printing Office), p. 407474.

1973b. Radiolaria from DSDP Leg 20. In Heezen, B. C., MacGregor, I. D., et al., Initial Reports of the Deep Sea Drilling Project, Volume 20: Washington (U.S. Government Printing Office), p. 249-305.

Habib, D., 1972. Dinoflagellate stratigraphy, Leg 11, Deep Sea Drilling Project. In Hollister, C. D., Ewing, J. I., et al., Initial Reports of the Deep Sea Drilling Project, Volume 11: Washington (U.S. Government Printing Office), p. 367. 425.

Haeckel, E., 1881. Entwurf eines Radiolarien-Systems auf Grund von Studien der Challenger-Radiolarien: Jena. $Z$. Med. Naturwiss., v. 15 (new ser. v. 8), no. 3, p. 418-472.

1887. Report on the Radiolaria collected by H. M. S. Challenger during the years 1873-76: Rept. Voyage Challenger, Zool., v. 18, p. i-1803.

Heitzer, I., 1930. Die Radiolarienfauna der mitteljurassischen Kieselmergel im Sonnwendgebirge: Jahrb. Geol. Bundesanst., v. 80, p. 381-406.

Herm, D., 1962. Stratigraphische und mikropaläontologische Untersuchungen der Oberkreide im Lattengebirge und Nierental (Gosaubecken von Reichenhall und Salzburg): Abhandl. Kgl. Bayer. Akad. Wiss., math.-naturw. Kl., neue Folge, no. 104, p. 1-110.

Hojnos, R., 1916. Beiträge zur Kenntnis der ungarischen fossilen Radiolarien: Földtani Közlöny, v. 46, p. 340-364.

Kling, S. A., 1971. Radiolaria: Leg 6 of the Deep Sea Drilling Project. In Fischer, A. G., Heezen, B. C., et al., Initial Reports of the Deep Sea Drilling Project, Volume 6: Washington (U.S. Government Printing Office), p. 1069 1117.

Kozlova, G. E. and Gorbovets, A. N., 1966. Radiolyarii verkhnemelovykh i verkhneeotsenovykh otlozhenii Zapadno-Sibirskoi Nizmennosti: Trudy vses. neft. nauchnoissled. geol.-razv. Inst., v. 248, p. 1-159.

McWhae, J. R. H., Playford, P. E., Lindner, A. W., Glenister, B. F., and Balme, B. E., 1958. The Stratigraphy of Western Australia: J. Geol. Soc. Australia, v. 4, no. 2, p. 1-161.

Moore, T. C., Jr., 1973. Radiolaria from Leg 17 of the Deep Sea Drilling Project. In Winterer, E. L., Ewing, J. I., et al., Initial Reports of the Deep Sea Drilling Project, Volume 
17: Washington (U.S. Government Printing Office), p. $797-$ 869.

Parona, C. F., 1890, Radiolarie nei noduli selciosi del calcare giurese di Cittiglio presso Laveno: Soc. Geol. Ital. Boll., v. 9 , no. 1, p. $1-46$.

Pessagno, E. A., Jr., 1963. Upper Cretaceous Radiolaria from Puerto Rico: Micropaleontology, v. 9, no. 2, p. 197-214. 1973. Upper Cretaceous Spumellariina from the Great Valley sequence, California Coast Ranges: Am. Paleontol. Bull., v. 63 , no. 276 , p. $45-102$.

In press. Radiolarian zonation and stratigraphy of the upper Cretaceous portion of the Great Valley sequence, California Coast Ranges: Micropaleontology Spec. Paper 1.

Petrushevskaya, M. G., 1972. Biostratigrafiya glubokovodnykh chetvertichnykh osadkov po dannym radiolyarievogo analyza: Okeanologiya, v: 12 , no. 1, p. 71-86.

Petrushevskaya, M. G. and Kozlova, G. E., 1972. Radiolaria: Leg 14, Deep Sea Drilling Project. In Hayes, D. E., Pimm, A. C., et al., Initial Reports of the Deep Sea Drilling Project, Volume 14: Washington (U.S. Government Printing Office), p. 495-648.

Premoli Silva, I. and Bolli, H. M., 1973. Late Cretaceous to Eocene planktonic foraminifera and stratigraphy of Leg 15 sites in the Caribbean Sea. In Edgar, N. T., Saunders, J. B., et al., Initial Reports of the Deep Sea Drilling Project, Volume 15: Washington (U.S. Government Printing Office), p. 475-497.

Renz, G. W. In preparation. Radiolaria from Leg 27 of the Deep Sea Drilling Project. In Heirtzler, J. R., Veevers, John J., et al., Initial Reports of the Deep Sea Drilling Project, Volume 27: Washington (U.S. Government Printing Office).

Riedel, W. R., 1953. Mesozoic and late Tertiary Radiolaria of Rotti: J. Paleontol., v. 27, no. 6, p. 805-813.

Riedel, W. R. and Funnell, B. M., 1964. Tertiary sediment cores and microfossils from the Pacific Ocean floor: Quart. J. Geol. Soc. London, v. 120, p. 305-368.

Riedel, W. R. and Sanfilippo, A., 1970. Radiolaria, Leg 4, Deep Sea Drilling Project. In Bader, R. G., Gerard, R. D., et al., Initial Reports of the Deep Sea Drilling Project, Volume 4: Washington (U.S. Government Printing Office), p. $503-575$.

1971. Cenozoic Radiolaria from the western tropical Pacific, Leg 7. In Winterer, E. L., Riedel, W. R., et al. Initial Reports of the Deep Sea Drilling Project, Volume 7: Washington (U.S. Government Printing Office), p. 15291672.

1973. Cenozoic Radiolaria from the Caribbean, DSDP Leg 15. In Edgar, N. T., Saunders, J. B., et al., Initial Reports of the Deep Sea Drilling Project, Volume 15: Washington (U.S. Government Printing Office), p. 705751.

Roep, T. B., 1972. Stratigraphy of the "Permo-Triassic" Saladilla formation and its tectonic setting in the Betic of Malaga (Velez Rubio region, SE Spain): Proc. K. Nederl. Akad. Wetensch. Amsterdam, ser. B, v. 75, no. 3, p. 223247.

Roth, P. H., 1973. Calcareous nannofossils-Leg 17, Deep Sea Drilling Project. In Winterer, E. L., Ewing, J. I., et al., Initial Reports of the Deep Sea Drilling Project, Volume 17: Washington (U.S. Government Printing Office), p. $695-$ 795.

Rüst, D., 1885. Beiträge zur Kenntniss der fossilen Radiolarien aus Gesteinen des Jura: Palaeontographica, v. 31 (ser. 3, v. 7), p. 269-322.
1898. Neue Beiträge zur Kenntniss der fossilen Radiolarien aus Gesteinen des Jura und der Kreide: Palaeontographica, v. 45 , p. 1-67.

Sanfilippo, A., Burckle, L. H., Martini, E., and Riedel, W. R., 1973. Radiolarians, diatoms, silicoflagellates and calcareous nannofossils in the Mediterranean Neogene: Micropaleontology, v. 19, no. 2, p. 209-234.

Sanfilippo, A. and Riedel, W. R., 1970. Post-Eocene "closed" theoperid radiolarians: Micropaleontology, v. 16, no. 4, p. 446-462.

Squinabol, S., 1903. Le Radiolarie di noduli selciosi nella Scaglia degli Euganei: Contribuzione I: Riv. Ital. Paleontol., v. 9, p. 105-150.

1904. Radiolarie cretacee degli Euganei: Atti Mem. R. Accad. Sci. Lett. Arti Padova, new ser. v. 20, p. 171-244. 1914. Contributo alla conoscenza dei Radiolarii fossili del Veneto. Appendice-Di un genere di Radiolari caratteristico del Secondario. Mem. Ist. Geol. R. Univ. Padova, v. 2, p. 249-306.

Tan Sin Hok, 1927. Over de samenstelling en het ontstaan van krijt en mergel-gesteenten van de Molukken: Jaar. Mijn. Ned. Oost-Indië, Verhandl., (1926), p. 1-165.

Wilcoxon, J. A., 1972. Upper Jurassic-Lower Cretaceous calcareous nannoplankton from the western North Atlantic Basin. In Hollister, C. D., Ewing, J. I., et al., Initial Reports of the Deep Sea Drilling Project, Volume 11: Washington (U.S. Government Printing Office, p. 427-457.

Wisniowski, T., 1889. Beitrag zur Kenntniss der Mikrofauna aus der oberjurassischen Feuersteinknollen der Umgegend von Krakau: Jahrb. K. K. Geol. Reichsanst., Jahrg. 1888, v. 38 , no. 4, p. $657-702$.

\section{PLATES}

Plates 1-11 constitute a type of synchronopticon, but not in the strict original sense (Riedel and Sanfilippo, 1971 , p. 1605). It has not been possible to select individual Cretaceous samples sufficiently diverse and representative to form the basis of a horizontal row-instead, pictures in most of the rows are taken from several samples. Moreover, each of the four rows represents two zones, with (where practicable) photographs from the younger zone placed high in the row, and those from the older zone low in the row. It should be emphasized that this synchronopticon is only a generalized guide to the stratigraphic ranges of species, precise information being given in Table 1.

In the explanations of the figures, the sample numbers and slide designations (in the form "Ph.2," "Sl.1," "Cse. 2," "C10.1091/2," etc.) indicate preparations in our collection at Scripps Institution of Oceanography (or, in the case of type specimens, preparations to be deposited in the U.S. National Museum, Washington, D.C.), and designations in the form "R45/1" indicate England Finder positions of the illustrated specimens on the slides.

Lack of uniformity in the quality of illustrations is due partly to the unsatisfactory preservation of some of these Mesozoic assemblages, and partly to the difficulty of finding mounting media with appropriate refractive indices. 



\section{PLATE 1}

All figures magnified $\times 140$.

Figures 1-3 Sphaerostylus lanceola

1. DSDP 99A-8-a, 112-116 cm, Sl., H35/0;

2. Pt. Sal, $\mathrm{C} 10.107, \mathrm{~S} 12 / 4$;

3. Pt. Sal, C10.108, Y36/0.

Figures 4, $5 \quad$ Form ancestral to Sphaerostylus lanceola

4. WRE 67-74, Sl.2, Y42/0;

5. WRE 67-74, SI.2, W47/2.

Figures 6-8 Staurosphaera septemporata

6. DSDP 167-72-2, 48-50 cm, Sl.2, G44/3;

7. DSDP 167-74-2, 74-76 cm, Sl.2, Q11/0;

8. DSDP 99A-8-1, $112-116 \mathrm{~cm}, \mathrm{Sl}$., S24/4.

Figures 9-11 Archaeospongoprunum cortinaensis

9. DSDP 146-15-5, 15-25 cm, Ph. 1, E30/3;

10. WRE 67-42, Ph.2, W57/2;

11. Beets R60-161, C10.152, H11/4. 
PLATE 1

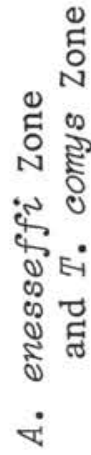

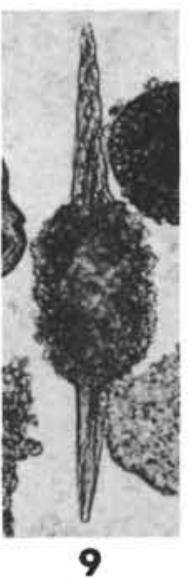

옹
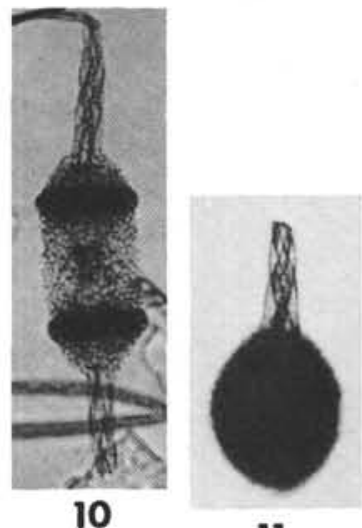

ค่

11
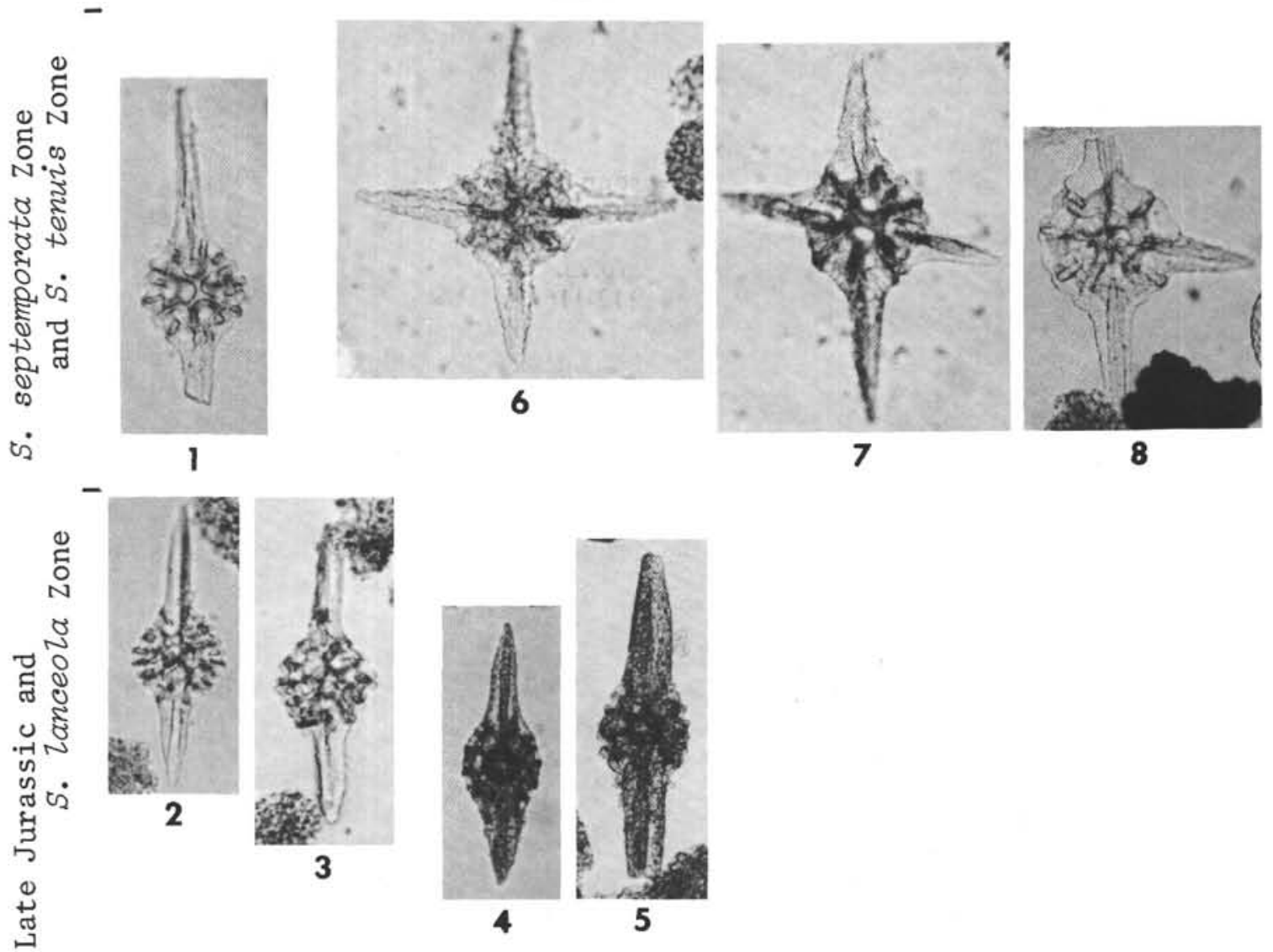


\section{PLATE 2}

All figures magnified $\times 140$.

Figures 1,2 Acanthocircus carinatus

1. DSDP 167-72-2, 48-50 cm, Sl.2, C45/3;

2. WRE 67-74, Sl.2, P49/2.

Figures 3-5 Acanthocircus dizonius

3. Beets R60-161, C10.152, C24/3;

4. Rotti $154, \mathrm{Cl} .42, \mathrm{~W} 22 / 0$;

5. DSDP $167-88, \mathrm{CC}, \mathrm{Sl} .2, \mathrm{~J} 21 / 3$.

Figure 6 Haliodictya hojnosi

WRE 67-74, Cs.2, V26/0.

Figures 7-11 Spongopyle insolita group

7. DSDP 164-11-1, 128-130 cm, Sl.2, K10/2;

8. DSDP 164-16-1, 141-143 cm, Sl.2, F16/0;

9. Beets R60-161, C10.152, V43/1;

10. DSDP 99A-8-1, 112-116 cm, Sl., Q22/3;

11. WRE $67-74, \mathrm{Sl} .2, \mathrm{Y} 41 / 3$.

Figures 12-14 Pseudoaulophacus pargueraensis

12. DSDP 146-27-1, 1-11 cm, Ph.2, D38/3;

13. DSDP $146-27-1,1-11 \mathrm{~cm}, \mathrm{Sl} .2, \mathrm{H} 54 / 0$;

14. WRE 67-42, SI.2, D25/1. 
RADIOLARIA

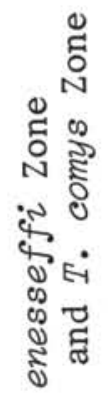

षं

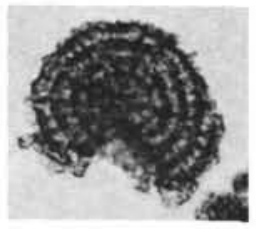

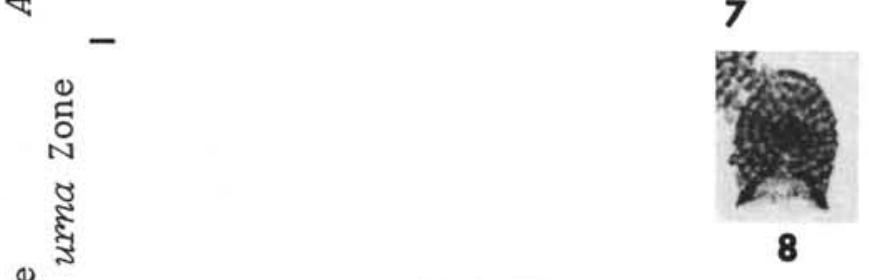

\section{PLATE 2}

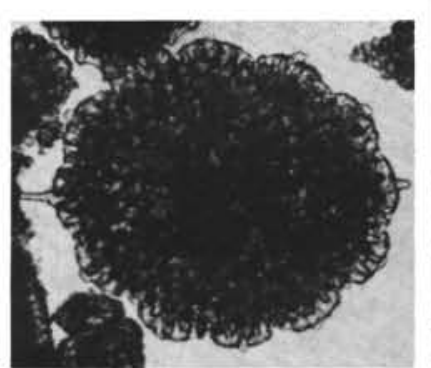

12

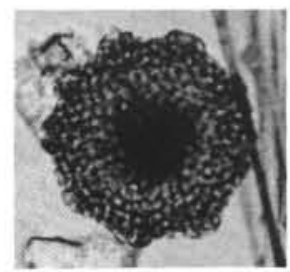

14

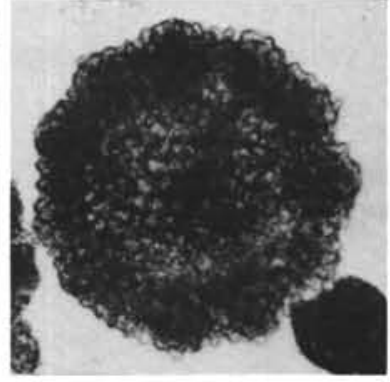

13
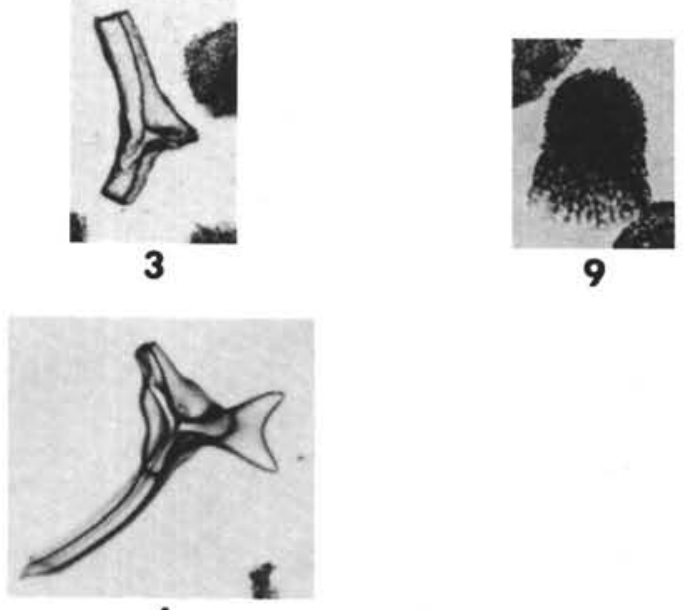

4
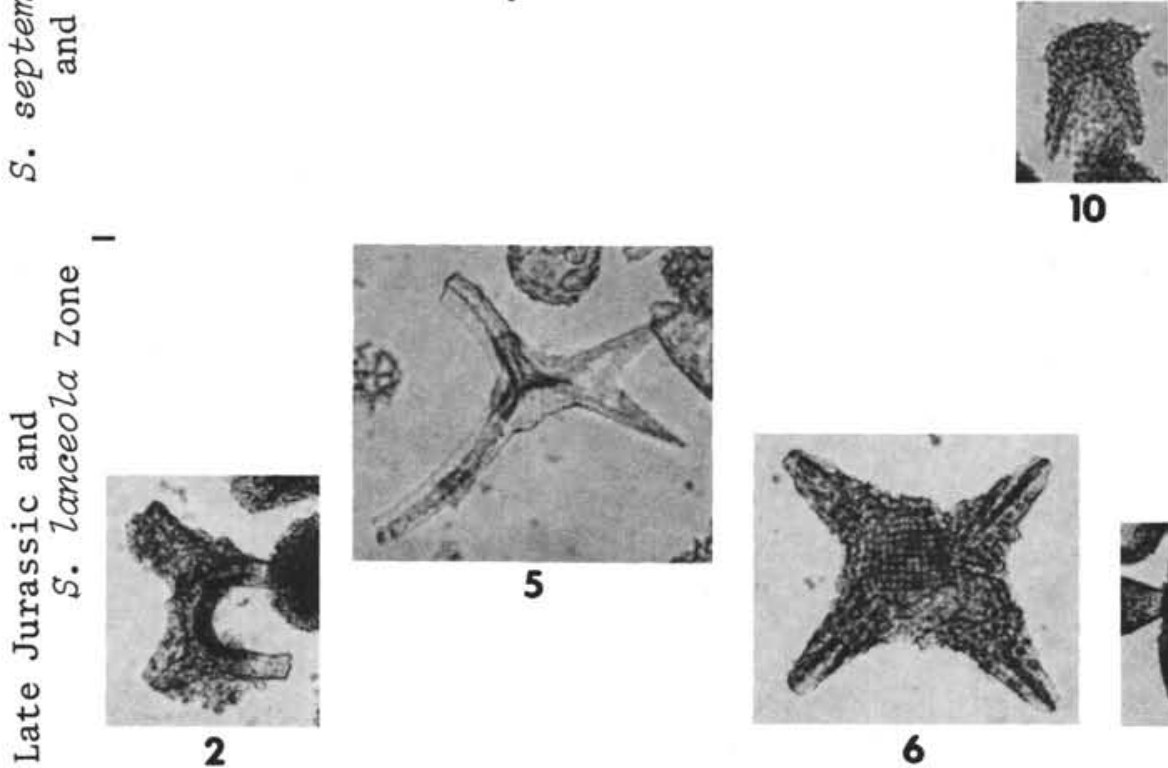

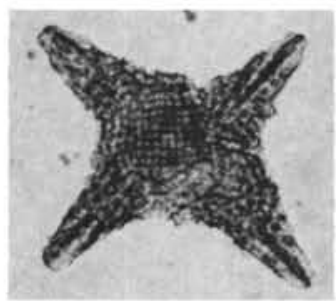

6

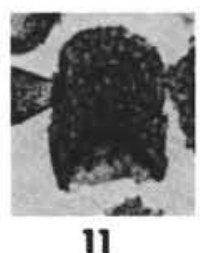




\section{PLATE 3}

All figures magnified $\times 140$.

Figures 1-3 Pseudoaulophacus superbus

1. DSDP 146-27-1, 1-11 cm, Sl.1, F28/0;

2. WRE $67-42, \mathrm{Sl} .1, \mathrm{~F} 33 / 4$;

3. DSDP 164-16-1, 141-143 cm, Sl.2, X31/1.

Figures 4-8 Spyrid (?) gen. et sp. indet.

4. Rotti 150, new Sl.2, Q51/2;

5. DSDP 99A-8-1, 112-116 cm, Sl., R20/2;

6. Pt. Sal, C10.107, L44/3;

7. Pt. Sal, C10.108, V45/0;

8. WRE $67-74, \mathrm{Sl} .2, \mathrm{E} 40 / 4$.

Figures 9-11 Bathropyramis spp.

9. DSDP 146-27-1, 1-11 cm, Ph.2, T43/0;

10. DSDP 146-27-1, 1-11 cm, Ph.1, J38/3;

11. DSDP $164-11-1,128-130 \mathrm{~cm}, \mathrm{Sl} .2, \mathrm{P} 37 / 3$.

Figure 12 Clathropyrgus titthium

WRE 67-42, Ph.1, S39/0. 
Plate 3
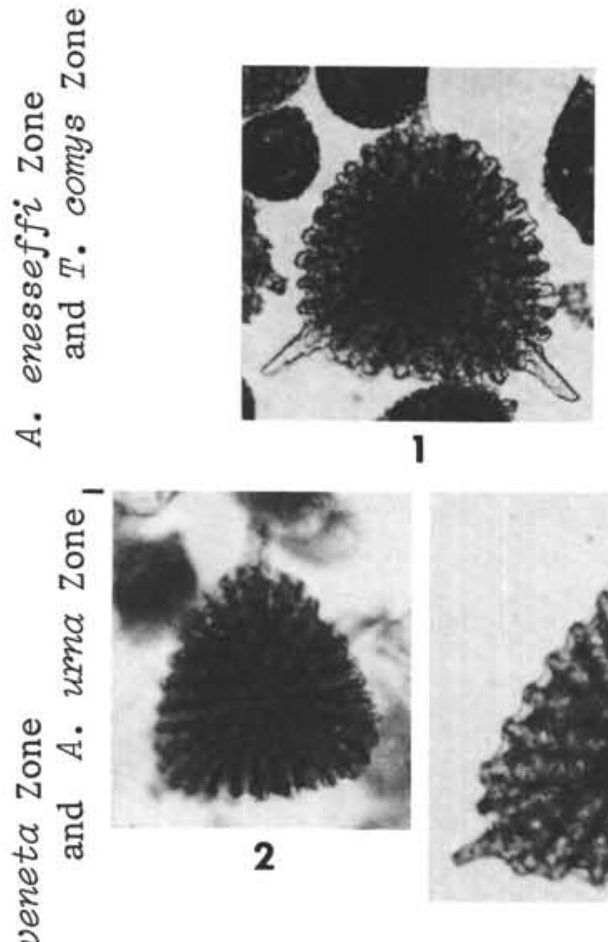

$\dot{0}$

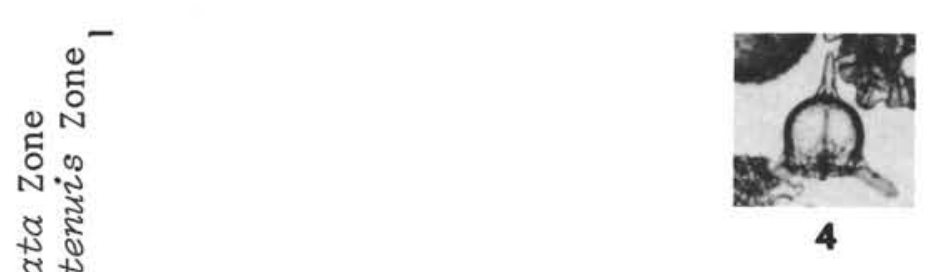

हैं

कू

के

نे

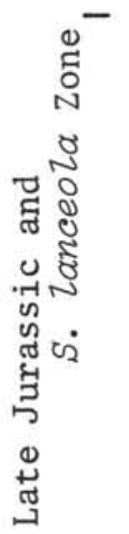
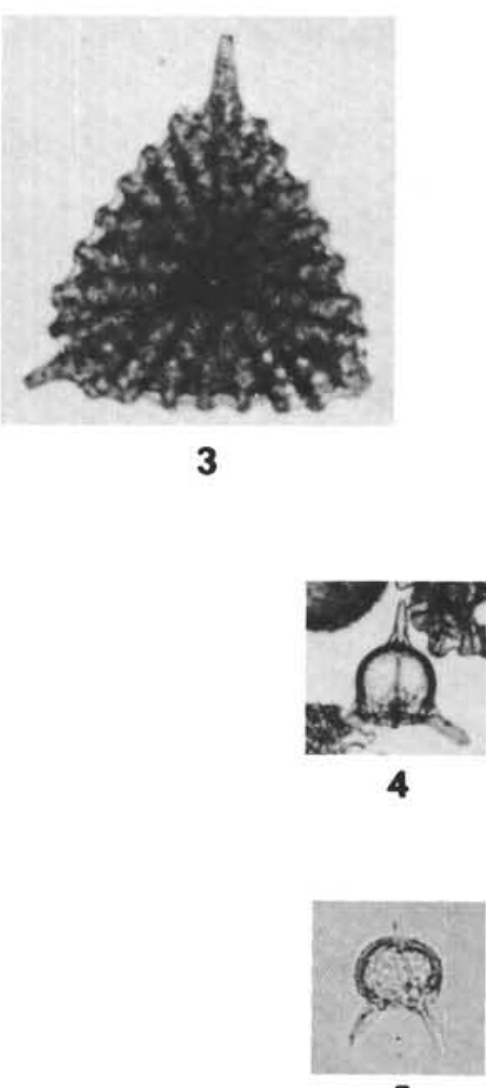

5

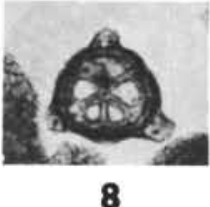

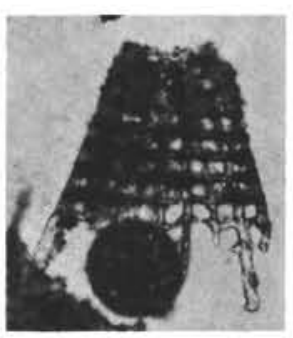

10

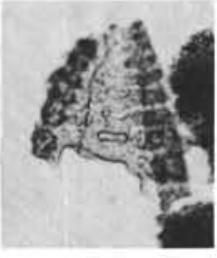

11

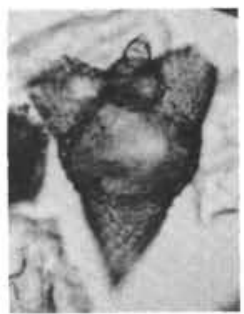

12

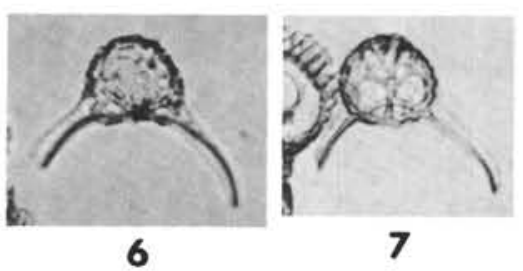




\section{PLATE 4}

All figures magnified $\times 140$.

Figures 1-3 Cyrtocalpis operosa

1. Gearle CC16, C10.81, 040/0;

2. Rotti $149, \mathrm{C} 7.1341 \frac{1}{2}, \mathrm{~F} 50 / 0$;

3. DSDP 99A-8-1, $112-116 \mathrm{~cm}, \mathrm{Sl}$., F21/4.

Figure 4 Dictyocephalus $\mathrm{sp}$.

DSDP 164-16-1, 141-143 cm, Sl.2, T24/4.

Figures 5,6 Dictyomitra boesii

5. DSDP $167-72-2,48-50 \mathrm{~cm}, \mathrm{Sl} .2, \mathrm{G} 43 / 4$;

6. DSDP $167-88, \mathrm{CC}, \mathrm{Sl} .2, \mathrm{X} 10 / 3$.

Figures 7-9 Dictyomitra lilyae

7. Beets R60-161, C10.152, V34/0;

8. DSDP 249-24-1, 106-108 cm, Sl.1, O18/0;

9. DSDP 249-24-1, 106-108 cm, Sl.1, R35/0.

Figures 10,11 Dictyomitra macrocephala

10. DSDP 167-62-2, 136-138 cm, Sl.1, D27/1;

11. DSDP 167-61-2, 104-106 cm, Sl.1, K44/2. 


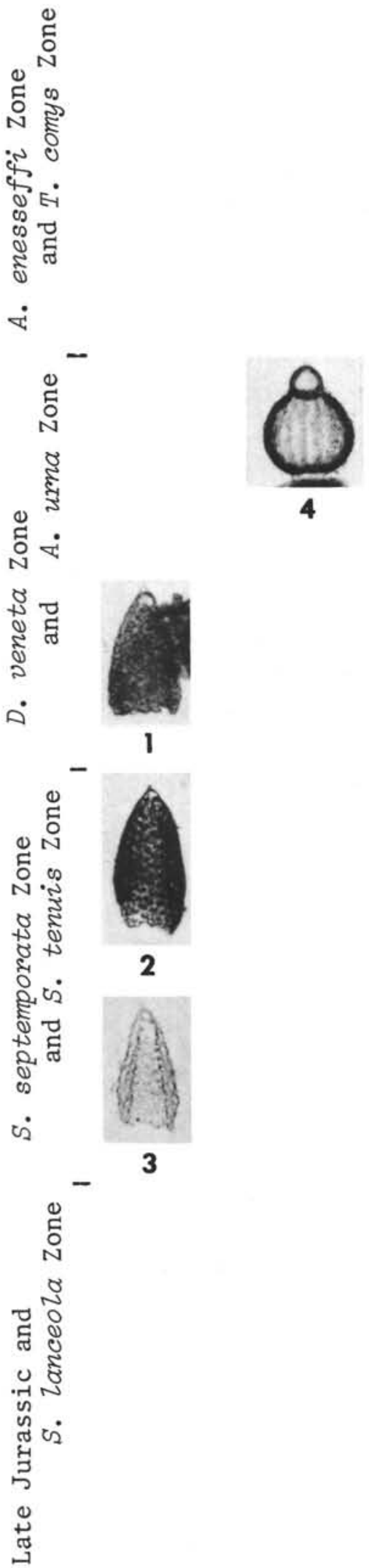

PLATE 4
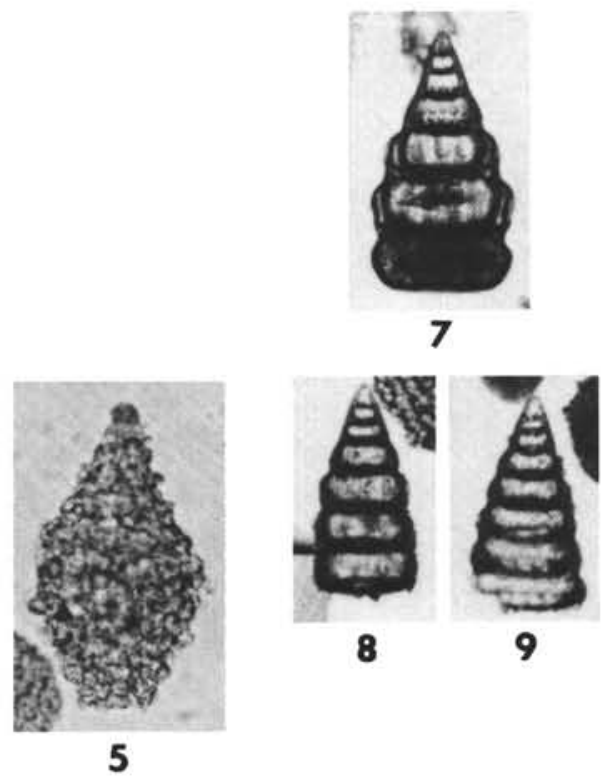

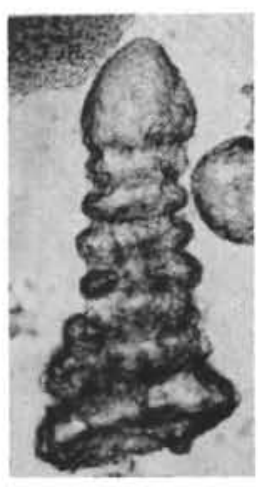

11

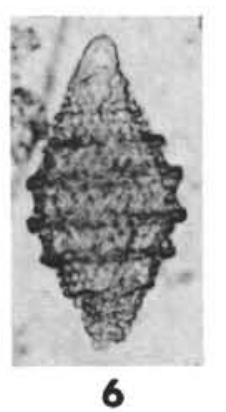

10
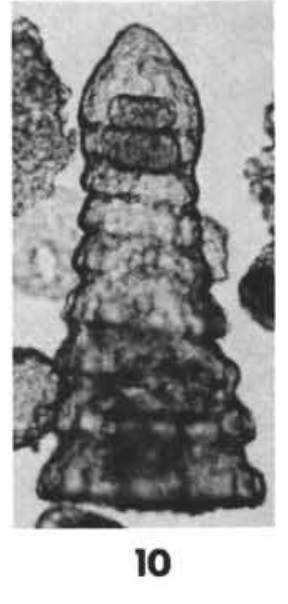
PLATE 5

All figures magnified $\times 140$.

Figures 1-4 Dictyomitra torquata

1. DSDP 146-27-1, 1-11 cm, Sl.1, G47/0;

2. DSDP 146-27-1, 1-11 cm, Sl.2, L30/1;

3. WRE 67-42, Ph.2, 041/1;

4. DSDP 164-16-1, 141-143 cm, Sl.2, E33/4.

Figures 5,6 Dictyomitra veneta

5. DSDP 167-61-2, 104-106 cm, Sl.1, U44/0;

6. DSDP 167-62-2, 136-138 cm, Sl.1, R40/4.

Figure $7 \quad$ Eucyrtidium ptyctum

Pt. Sal, C10.107, G26/0.

Figure $8 \quad$ Eucyrtis bulbosus

Beets R60-161, C10.152, O25/4.

Figures 9-13 Eucyrtis hanni

9. Beets R60-161, C10.152, F41/2;

10. Beets R60-161, C10.152, B25/4;

11. Rotti $154, \mathrm{Cl} .42, \mathrm{C} 26 / 4$;

12. DSDP 99A-8-1, $112-116 \mathrm{~cm}, \mathrm{Sl} ., \mathrm{V} 34 / 3$;

13. Pt. Sal, C10.107, D26/2.

Figure $14 \quad$ Eucyrtis hanni?

WRE 67-74, Sl.4, M30/4. 


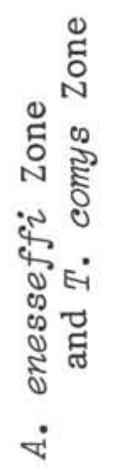

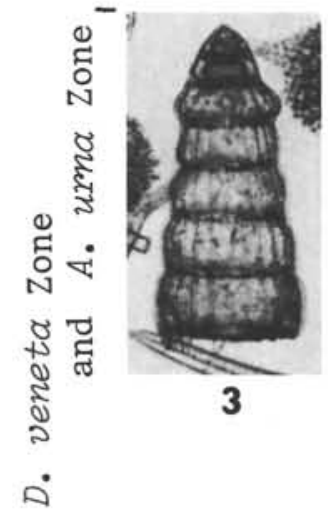

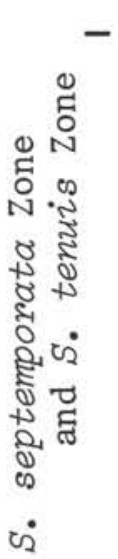

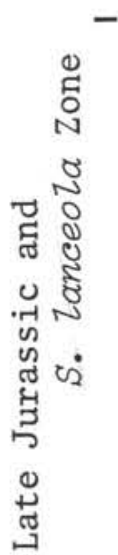

Plate 5
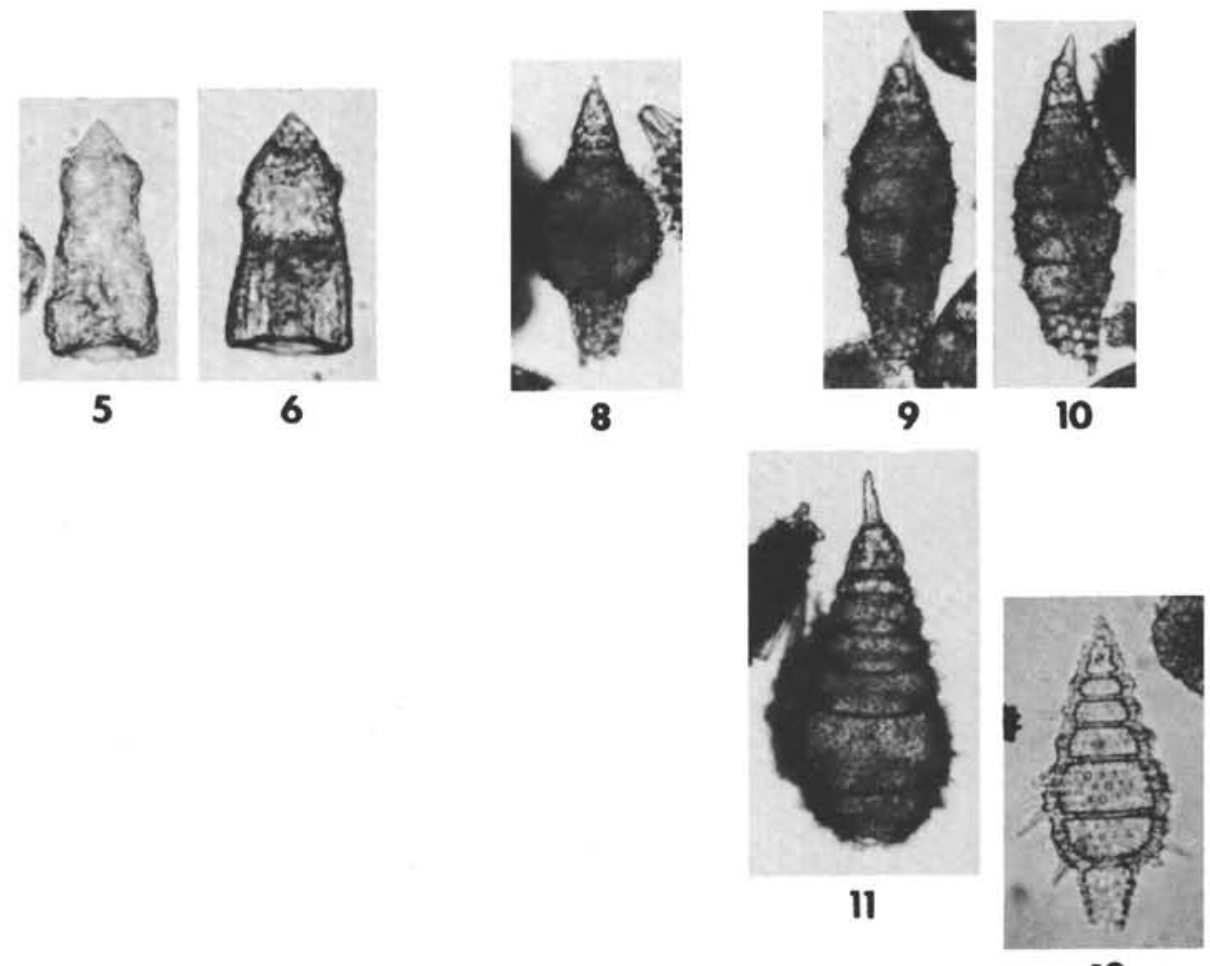

12
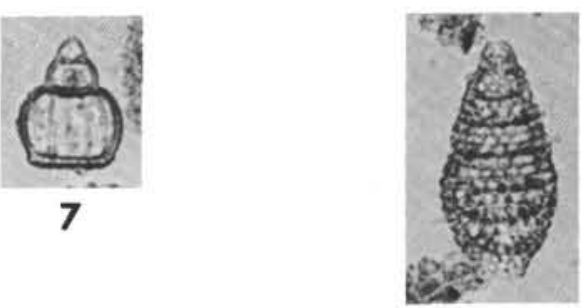

13

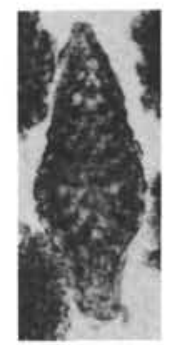

14 


\section{PLATE 6}

All figures magnified $\times 140$.

Figures 1-4 Hemicryptocapsa spp. cf. H. capita

1. DSDP 167-72-2, 48-50 cm, Sl.2, D33/0;

2. DSDP 99A-8-1, 134-136 cm, Sl.2, Q46/0;

3. Pt. Sal, C10.108, W28/4;

4. WRE $67-74, \mathrm{Sl} .2, \mathrm{~W} 48 / 0$.

Figures 5-7 Lithocampe chenodes

5. DSDP 167-74-2, 74-76 cm, Sl.2, J40/2;

6. Pt. Sal, $\mathrm{C} 10.108, \mathrm{X} 12 / 3$;

7. WRE $67-74$, Cs.1, X36/4.

Figures 8-10 Lithocampe elegantissima

8. DSDP 167-61-2, 104-106 cm, Sl.1, L15/4;

9. DSDP 167-62-2, 136-138 cm, SI.1, G30/2;

10. DSDP $167-72-2,48-50 \mathrm{~cm}, \mathrm{Sl} .2, \mathrm{U} 21 / 0$. 


\section{PLATE 6}

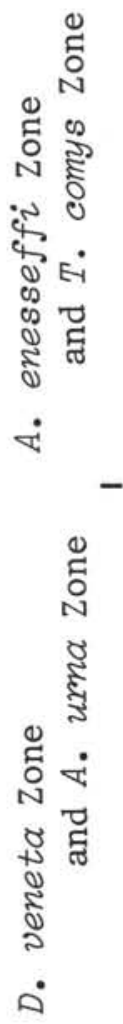
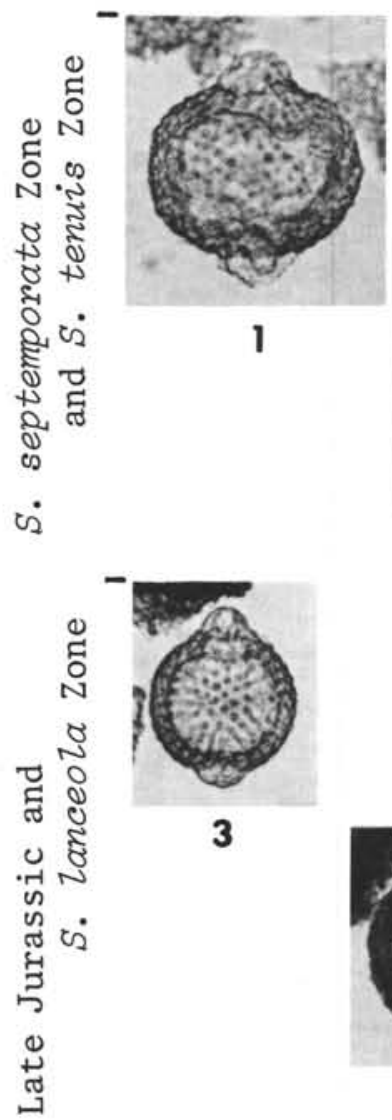

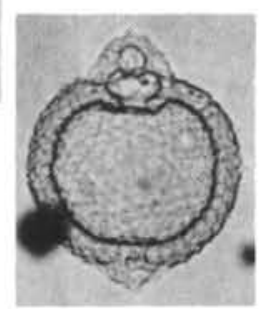

2

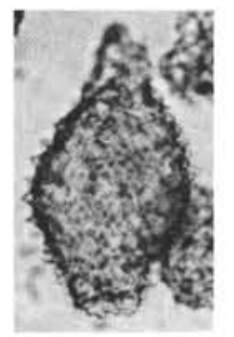

5
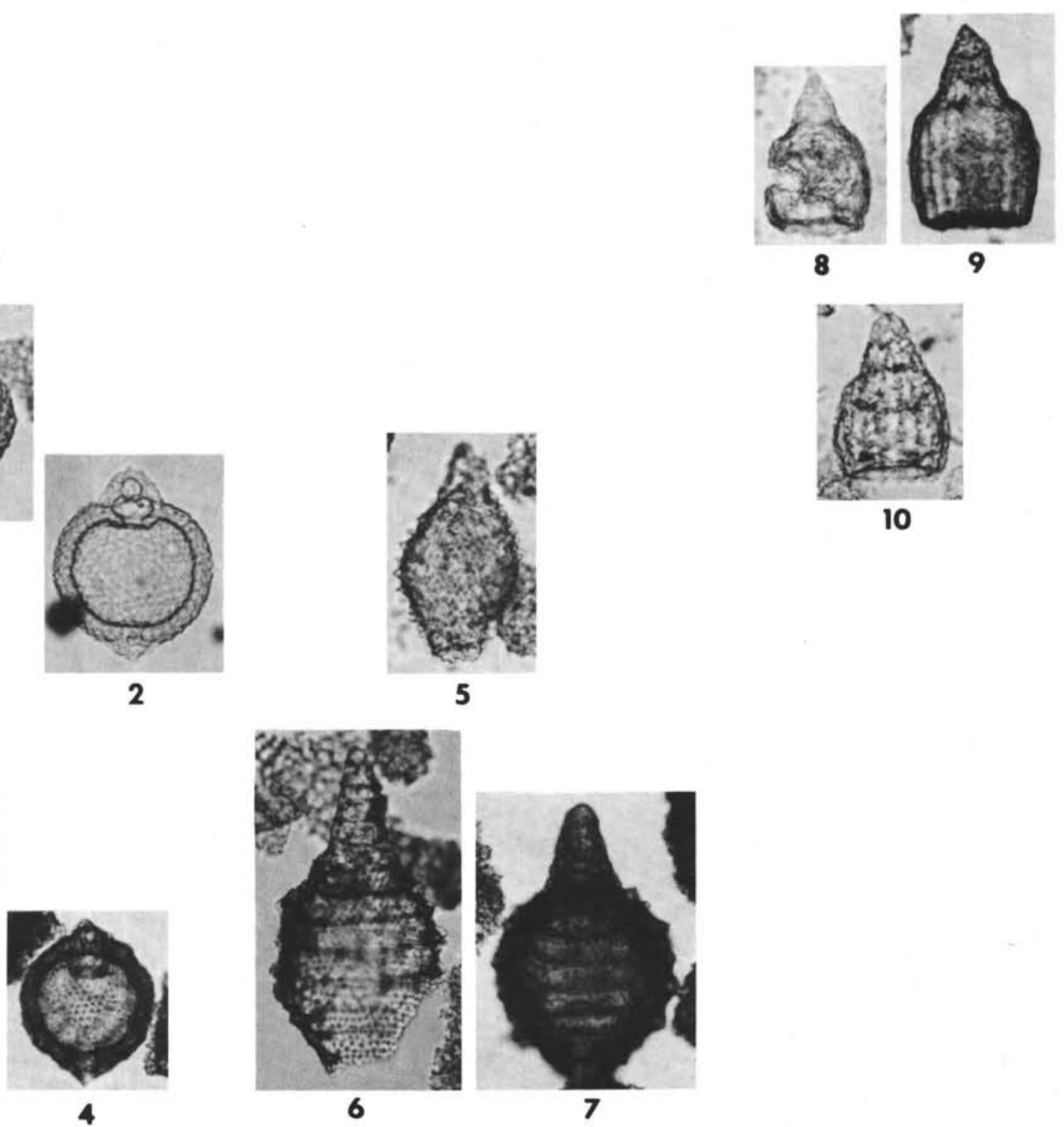


\section{PLATE 7}

All figures magnified $\times 140$.

Figures 1-4 Lithocampe mediodilatata

1. DSDP 99A-8-1, 112-116 cm, Sl., J14/2;

2. Pt. Sal, C10.108, $\mathrm{X} 32 / 1$;

3. WRE $67-74$, Cs.2, O47/0;

4. WRE 67-74, Cs.2, Q27/1. 


\section{PLATE 7}

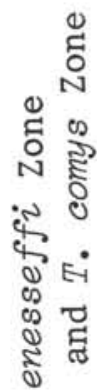

ष

్ㅗㅇ

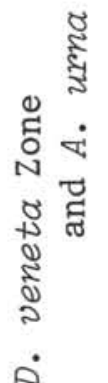

م
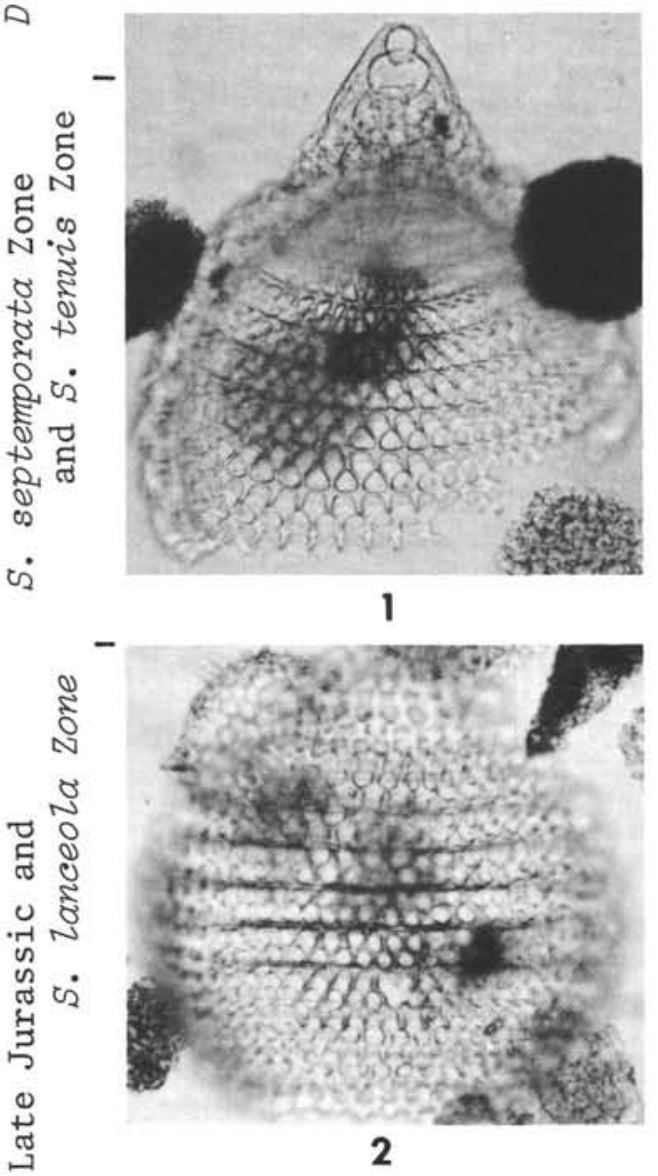

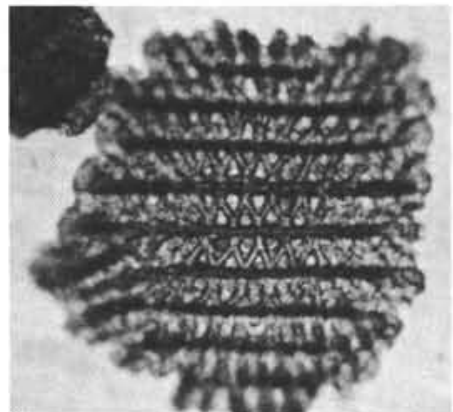

3

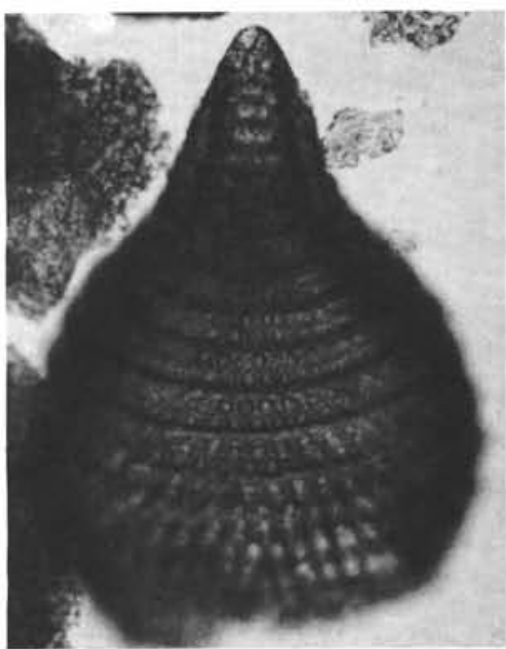

4 


\section{PLATE 8}

All figures magnified $\times 140$.

\section{Figures 1-4}

Lithocampe perampla

1. DSDP 99A-8-1, 82-84 cm, Sl.2, N12/0;

2. Pt. Sal, C10.107, X32/1;

3. WRE $67-74$, Cs. 2, N19/2;

4. WRE 67-74, SI.2, Q26/1.

Figure $5 \quad$ Podobursa pantanellii

Pt. Sal, C10.117, B42/3. 
PLATE 8

( )

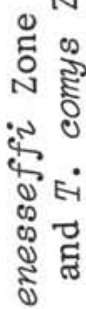

ष

్ㅗㅇ

है है

号

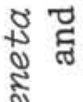

อิ

$\circ$

¿

N.N

म

$\checkmark$

مे

บิ

으

क

نे

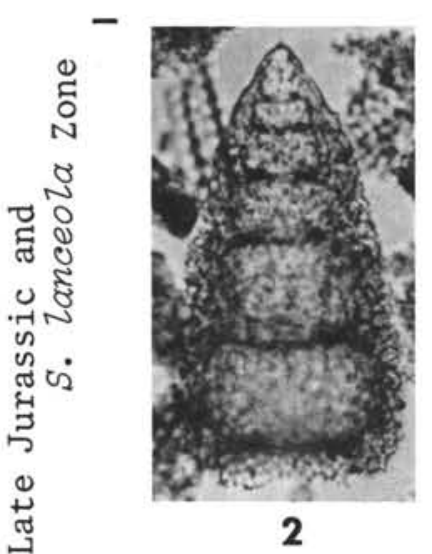

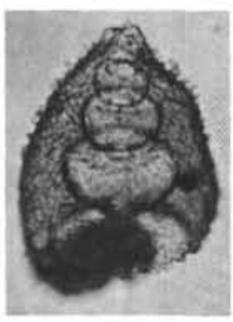

1

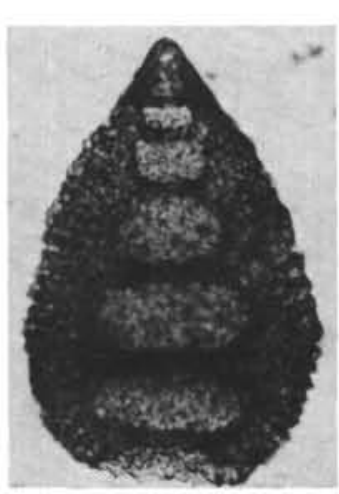

3
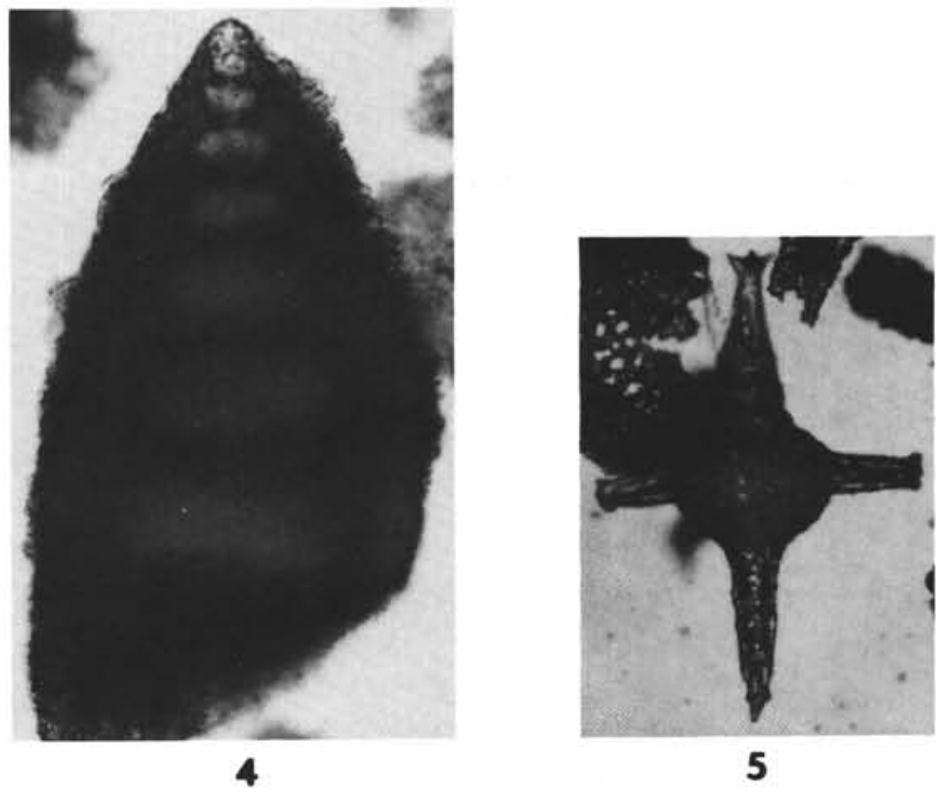
PLATE 9

All figures magnified $\times 140$.

Figures 1, 2 Theoperid gen. et sp. indet. cf. Podobursa sp.

1. DSDP 167-74-2, 74-76 cm, S1.2, C13/1;

2. WRE 67-74, Cs.2, H32/2.

Figure 3 Rhopalosyringium antirrhopum

DSDP 146-15-5, 15-25 cm, Ph.1, U18/0.

Figure $4 \quad$ Sethocapsa sp. cf. S. trachyostraca

Beets R60-161, C 10.152, G 49/2.

Figures 5-7 Sethocapsa trachyostraca

5. DSDP $167-72-2,48-50 \mathrm{~cm}, \mathrm{~S} 1.2, \mathrm{D} 32 / 2$;

6. DSDP 167-72, CC, S1.1, Y38/1;

7. DSDP 167-88, CC, S1.2 U38/4.

Figures 8-11 Solenotryma spp.

8. Gearle CC19, Ph.1, J28/2;

9. Rotti 149, C7.1341/2, C23/0;

10. WRE $67-74, \mathrm{~S} 1.2, \mathrm{~T} 30 / 0$;

11. WRE $67-74, \mathrm{~S} 1.2, \mathrm{~N} 44 / 2$.

Figures 12-14 Stichocapsa tenuis

12. Beets R60-161, C10.152, E22/2;

13. DSDP $167-70-2,36-40 \mathrm{~cm}, \mathrm{~S} 1.1, \mathrm{~K} 44 / 1$;

14. DSDP $167-70-2,36-40 \mathrm{~cm}, \mathrm{~S} 1.1, \mathrm{G} 12 / 3$. 
PLATE 9

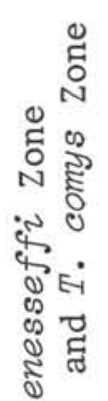

षं

品

हु

్ㅗㅇ

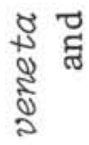

จ
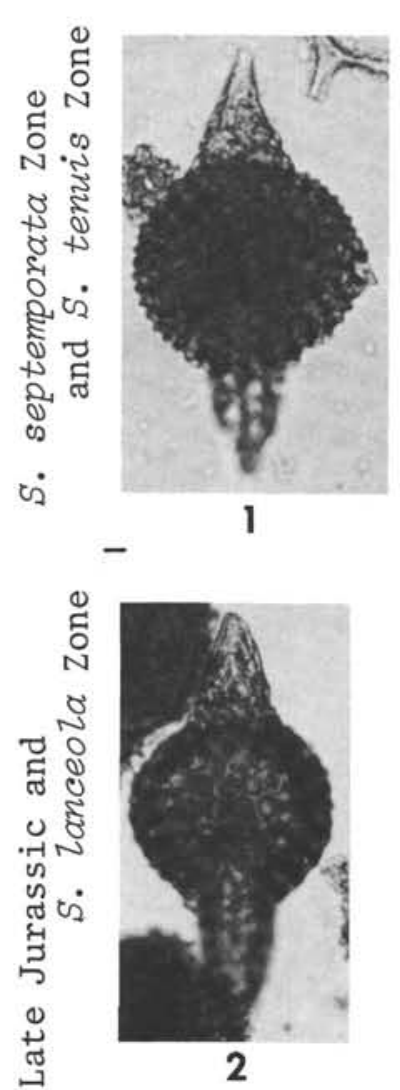
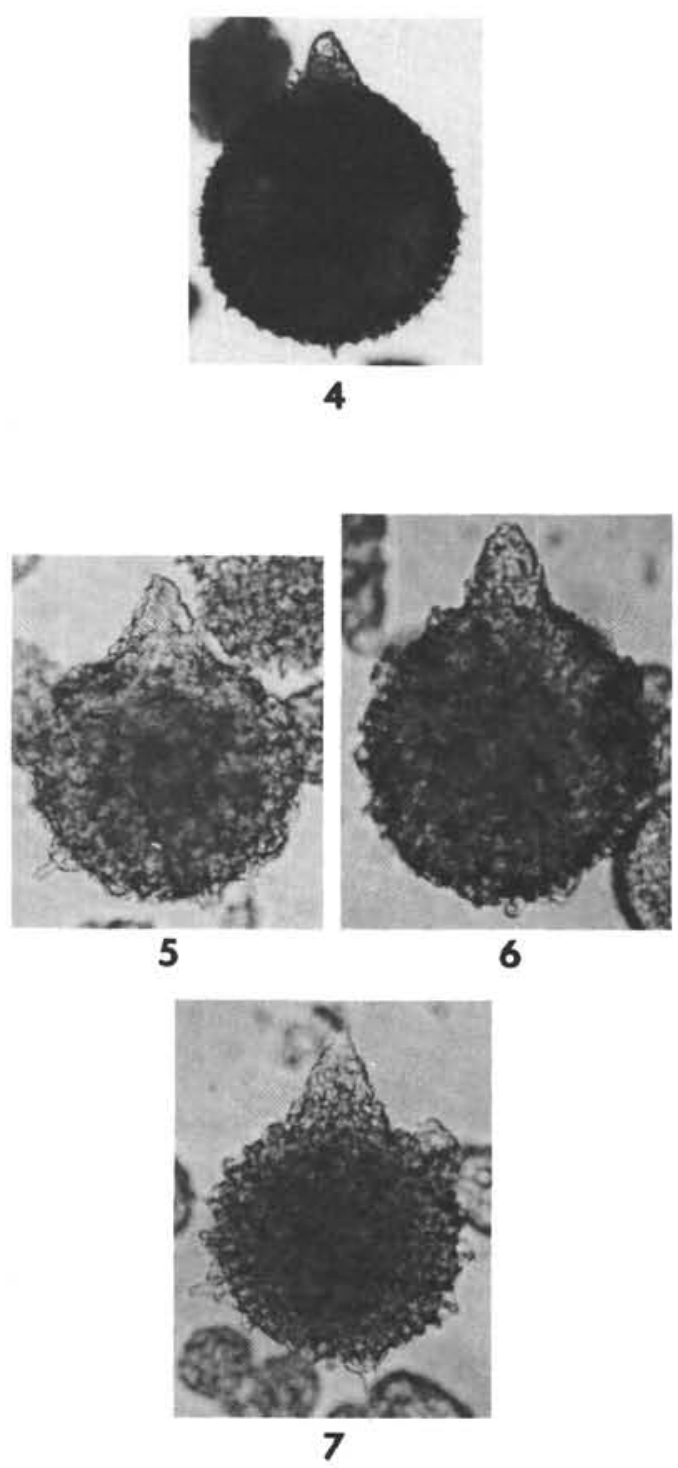
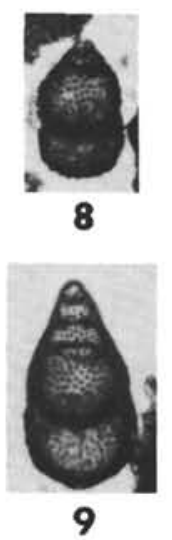

8
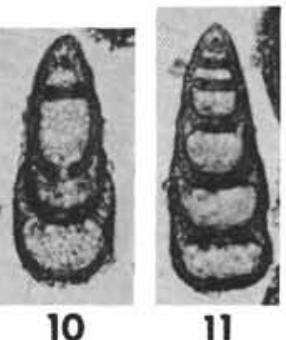
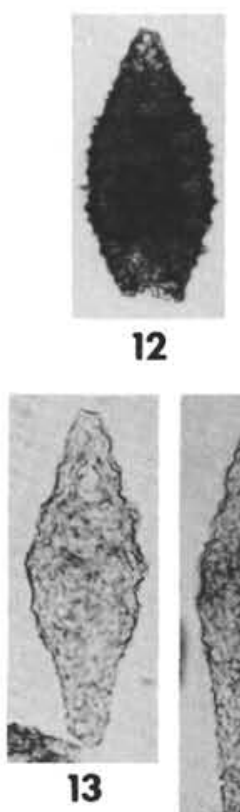

14 


\section{PLATE 10}

All figures magnified $\times 140$.

Figures 1-7 Stichomitra asymbatos group

1. DSDP 164-11-1, 128-130 cm, S1.2, W29/0;

2. Gearle CC19, C10.87, M35/4;

3. Beets R60-161, C10.152, W29/3;

4. Rotti 149, C7.1341/2, G21/2;

5. DSDP 99A-8-1, 112-116 cm, S1., J28/2;

6. WRE $67-74$, S1.2, Q18/0;

7. WRE $67-74, \mathrm{~S} 1.2, \mathrm{~K} 50 / 2$.

Figure $8 \quad$ Theocapsomma comys

DSDP 146-15-5, 15-25 cm, Ph.1, S22/0.

Figures 9-11 Theocorys antiqua

9. Beets R60-161, C10.152, W20/2;

10. DSDP 249-24-1, 106-108 cm, S1.1, F32/4;

11. Pt. Sal, C10.107, P20/3.

Figures 12, 13 Amphipyndax enesseffi

12. DSDP 164-11-1, 130-136 cm, S1.2, D28/2;

13. DSDP $164-11-1,130-136 \mathrm{~cm}, \mathrm{~S} 1.2, \mathrm{U} 23 / 0$. 


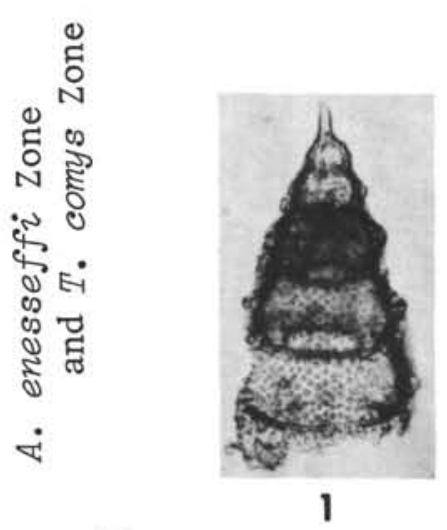

Plate 10

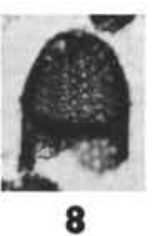

怘
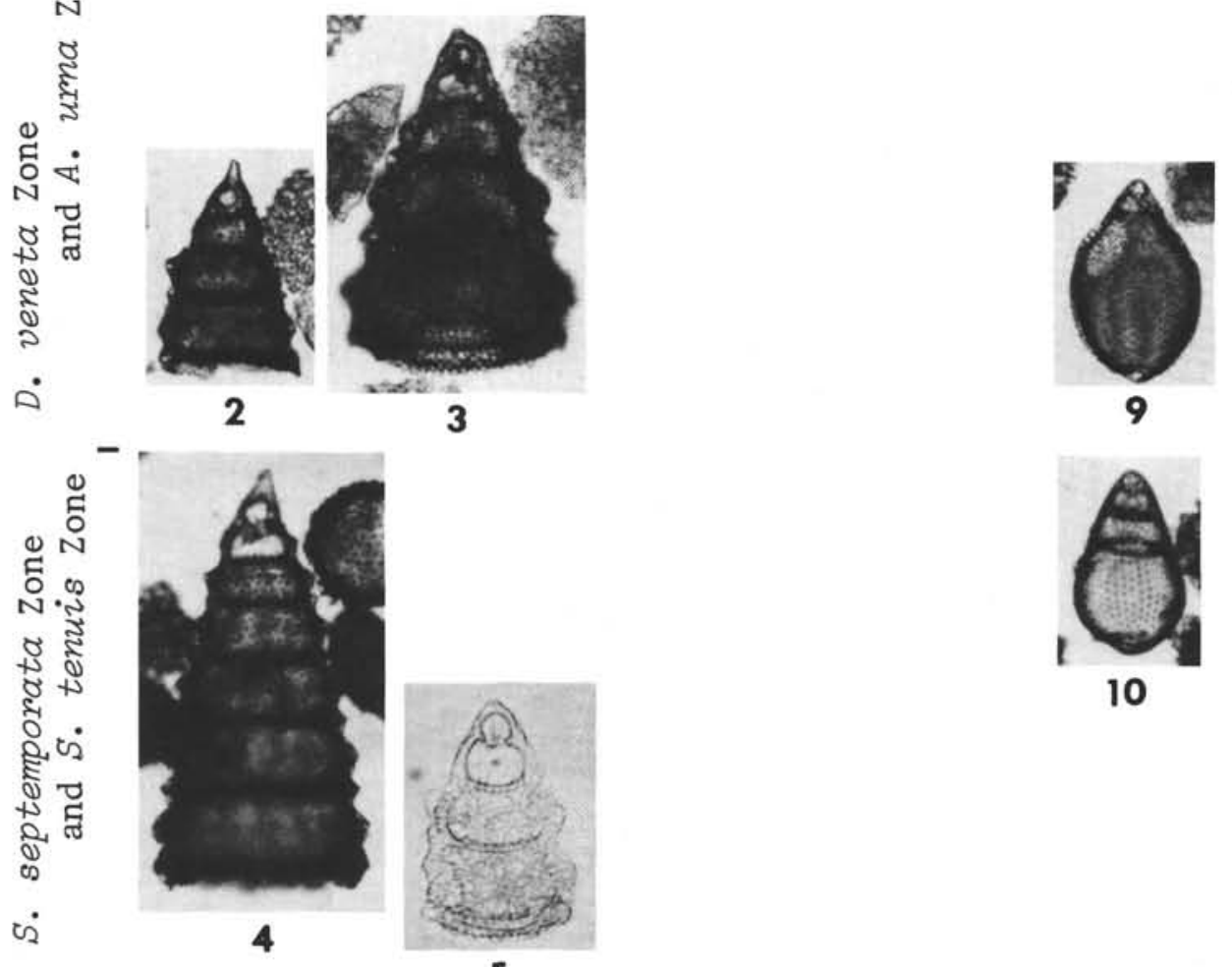

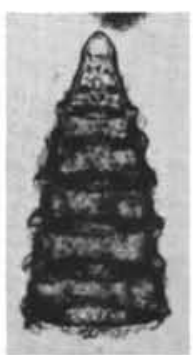

12

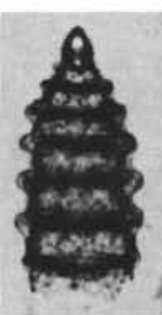

13
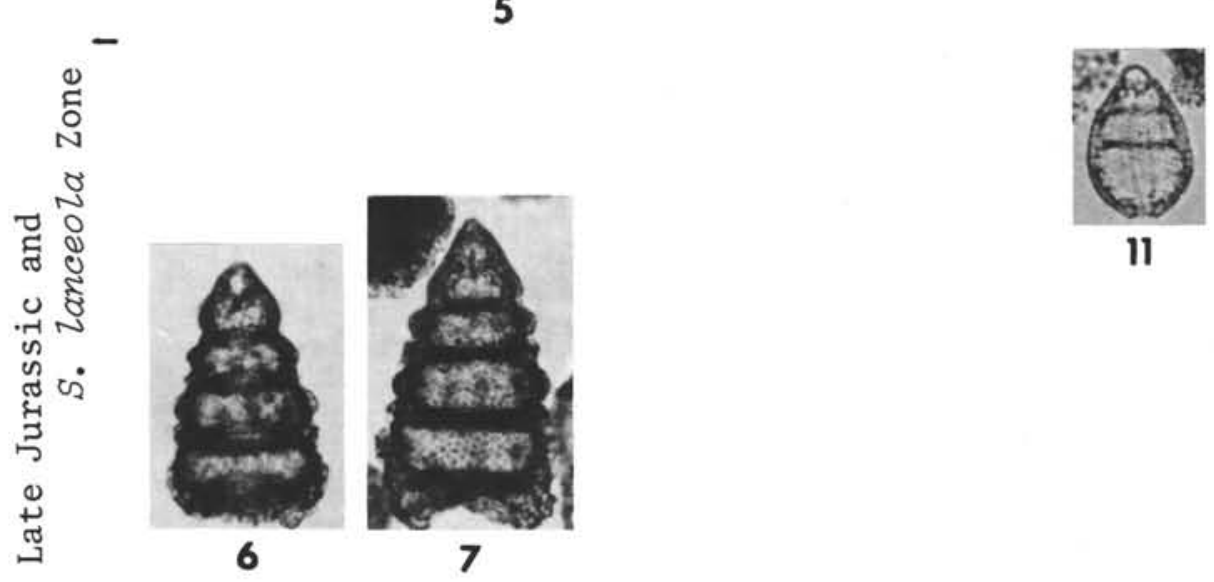

11 
PLATE 11

All figures magnified $\times 140$.

Figures 1-3 Amphipyndax stocki

1. DSDP 146-15-5, 15-25 cm, Ph.1, V47/3;

2. WRE 67-42, Ph.1, G24/0;

3. Rotti 384, Cl.676, U39/0.

Figures 4-6 Artostrobium urna

4. DSDP 146-15-5, 15-25 cm, Ph.1, O31/0;

5. WRE 67-42, Ph.2, V58/2;

6. WRE 67-42, Ph.2, D42/0.

Figure $7 \quad$ Theocampe ixys

DSDP 146-15-5, 15-25 cm, Ph.1, L34/4.

Figures 8-10 Theocampe salillum

8. DSDP $164-11-1,130-136 \mathrm{~cm}, \mathrm{~S} 1.2, \mathrm{G} 18 / 1$;

9. WRE 67-42, Ph.2, L24/2;

10. WRE 67-42, Ph.2, S46/0.

Figure 11 Afens liriodes

DSDP 146-27-1, 1-11 cm, S1.2, S32/1. 
PLATE 11
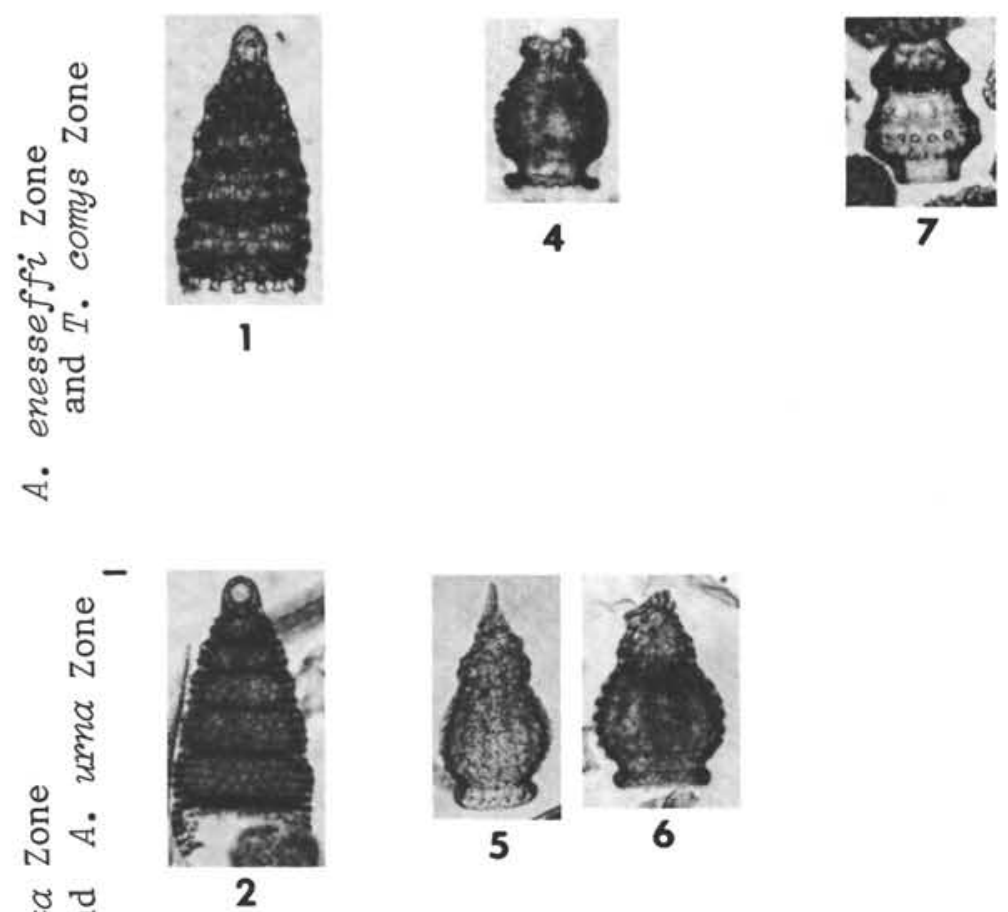

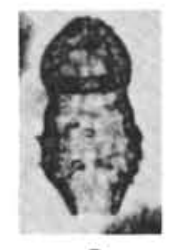

8

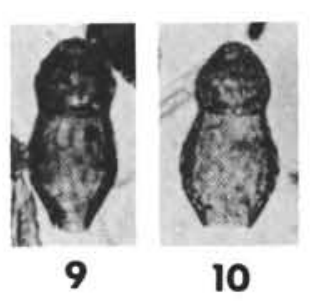

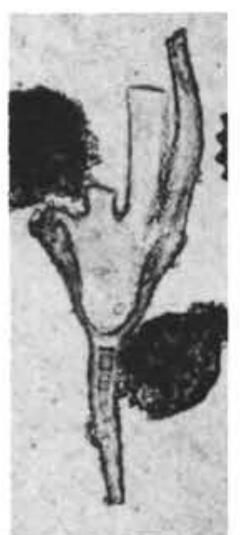

11

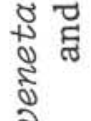

ค่

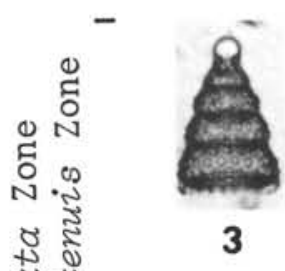

$8+$

हैं

\&

क

$\dot{ن}$

ฏ

चี

- $\begin{aligned} & -1 \\ & \text { ก }\end{aligned}$

in.

๘ึ

ॐ

$\stackrel{\oplus}{\stackrel{0}{9}}$ 


\section{PLATE 12}

All figures magnified $\times 255$.

Figure 1 Form ancestral to Sphaerostylus lanceola WRE 67-74, S1.2, Y42/0.

Figures 2, 3 Haliodictya hojnosi

2. Holotype, WRE $67-74, \mathrm{~S} 1.4$, O46/2;

3. WRE 67-74, S1.4, J57/0.

Figure $4 \quad$ Spongy form resembling Paronaella (?) diamphidia Foreman (1973a, p. 262, pl. 8, fig. 3, 4)

WRE 67-74, S1.2, K46/4.

Figure $5 \quad$ Spyrid (?) gen. et sp. indet.

Pt. Sal, C10.108, J31/1.

Figures 6-8 Clathropyrgus bumastus

6. Holotype, DSDP $146-30-2,79-85 \mathrm{~cm}, \mathrm{~S} 1.1$, F21/1;

7. DSDP 146-30-2, 79-85 cm, S1.1, J29/0;

8. DSDP 146-30-2, 79-85 cm, S1.2, Z23/3.

Figures 9-12 Clathropyrgus titthium

9. A specimen with the terminal segment not quite as hemispherical as in $C$. bumastus, DSDP 146-30-2, 79-85 cm, S1.1, Y19/0;

10. Holotype, DSDP 164-16-1, 141-143 cm, S1.1, U20/0;

11. DSDP 164-16-1,141-143 cm, S1.2, L34/2;

12. DSDP 164-16-1, 141-143 cm, S1.3, L28/1.

Figure 13 Dictyomitra lilyae

Beets R60-161, C10.152, X34/2.

Figures 14, 15 Eucyrtidium ptyctum

14. Holotype, Pt. Sal, C10.108, O24/2;

15. Pt. Sal, C0.108, S27/4.

Figures 16-18 Eucyrtis hanni

16. Rotti 150, new S1.1, F13/0;

17. Rotti 149, new S1.1, P36/3;

18. DSDP 99-A-8-1, 112-116 cm, S1., V34/3. 
PLATE 12
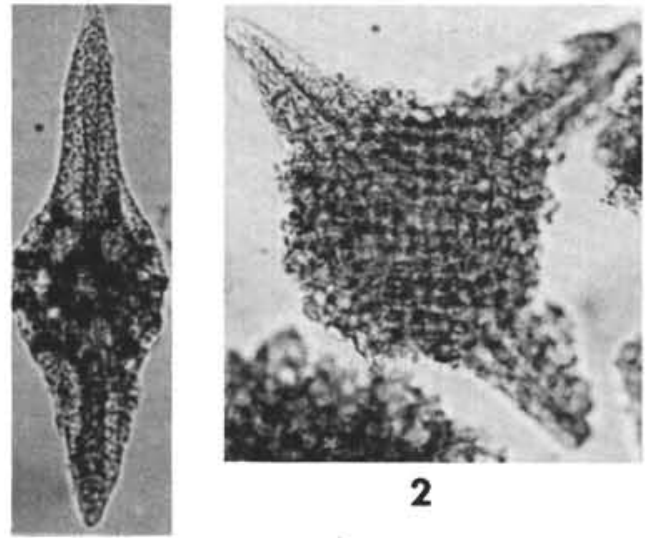

2

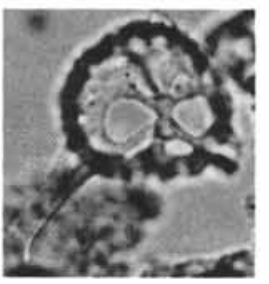

5

4
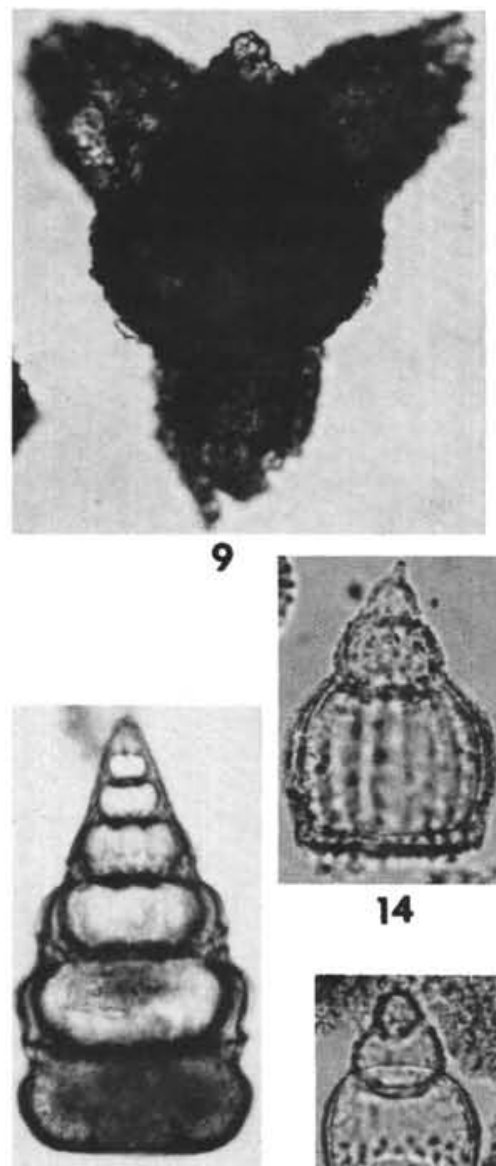

13

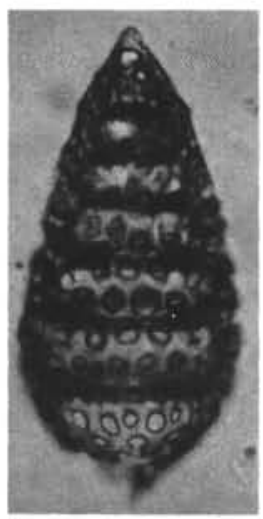

16

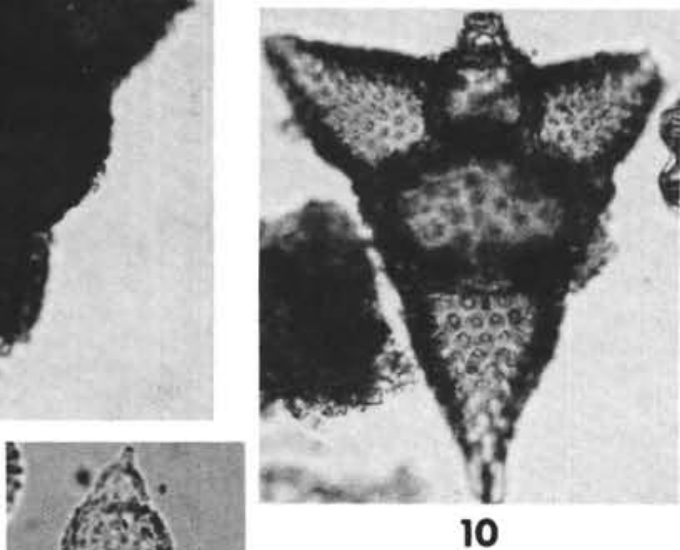

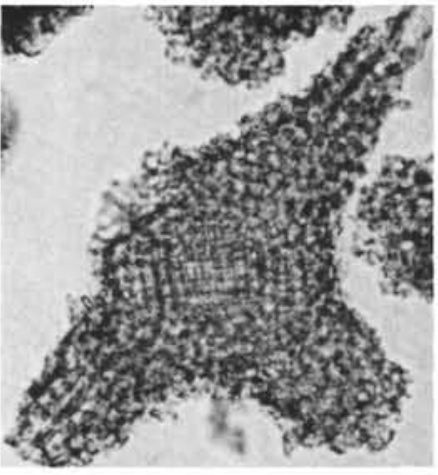

3
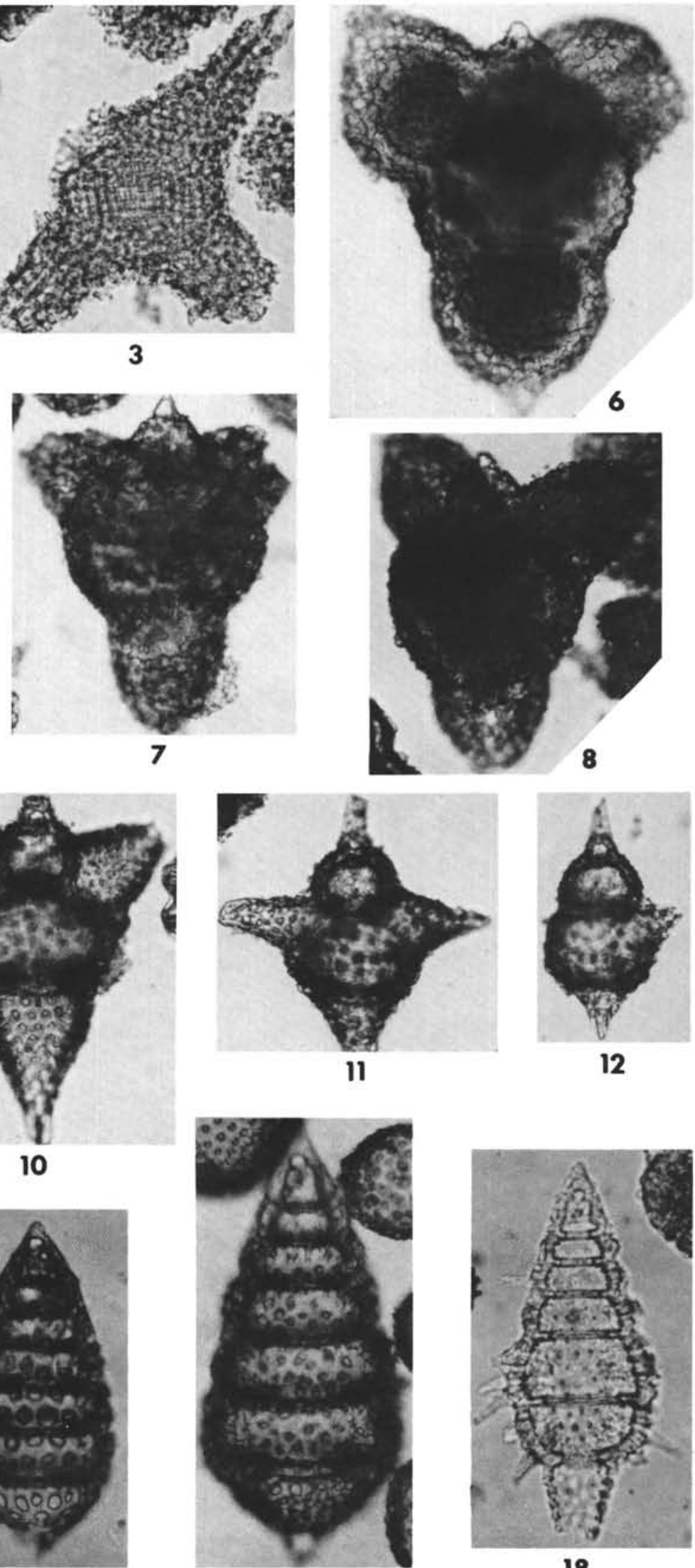

17

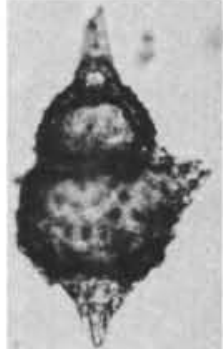

12

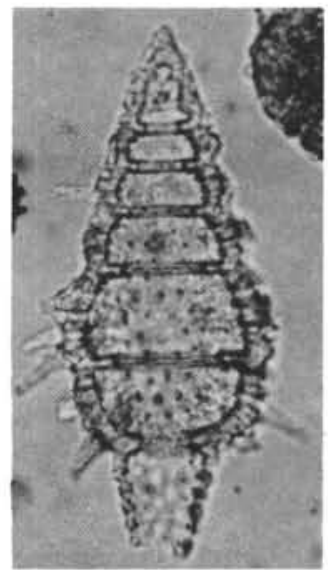

18 


\section{PLATE 13}

All figures magnified $\times 255$ unless otherwise indicated.

Figure 1 Fragment of Lithocampe chenodes, showing nature of pores and shell surface

Pt. Sal. C10.118, U21/1.

Figures 2-4 Lithocampe elegantissima

2. DSDP $195-3$, CC, S1.1, P18/0;

3. DSDP $169-9$, CC, S1.2, U33/0;

4. DSDP 167-62-2, 136-138 cm, S1.1, G30/2.

Figure $5 \quad$ Sethamphora pulchra

DSDP 169-9, CC, S1.2, W41/0.

Figure $6 \quad$ Podobursa pantanellii

Pt. Sal, C10.118, L19/3.

Figure $7 \quad$ Podobursa sp. with four or more spines on the inflated segment

DSDP 167-72-2, 48-50 cm, S1.1, O12/2 (magnification $\times 150$ ).

Figures 8-10 Rhopalosyringium antirrhopum

8. Holotype, DSDP 146-15-5, 15-25 cm, S1.2, S24/1;

9. DSDP $146-15-5,15-25 \mathrm{~cm}, \mathrm{~S} 1.2, \mathrm{P} 34 / 4$;

10. DSDP 146-15-5, $15-25 \mathrm{~cm}, \mathrm{~S} 1.3, \mathrm{Y} 13 / 3$.

Figure $11 \quad$ Solenotryma $\mathrm{sp}$.

WRE 67-74, Ph.1, W54/2.

Figures 12, 13 Theocampe ixys

12. Holotype, DSDP 170-9, CC, S1.2, T44/1;

13. DSDP 170-9, CC, S1.2, P8/2.

Figures 14-16 Afens liriodes

14. DSDP 146-15-5, 15-25 cm, Ph.1, O37/2;

15. Holotype, DSDP $146-15-5,15-25 \mathrm{~cm}, \mathrm{~S} 1.2$, $\mathrm{V} 32 / 3$;

16. DSDP 146-15-5, 15-25 cm, S1.3, R41/4. 
PLATE 13

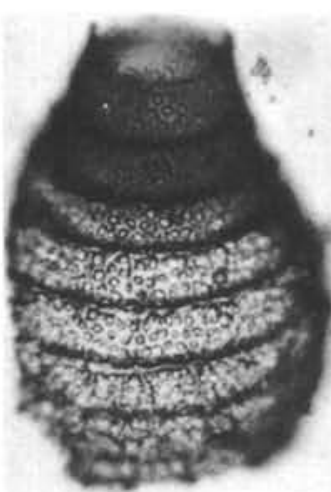

1

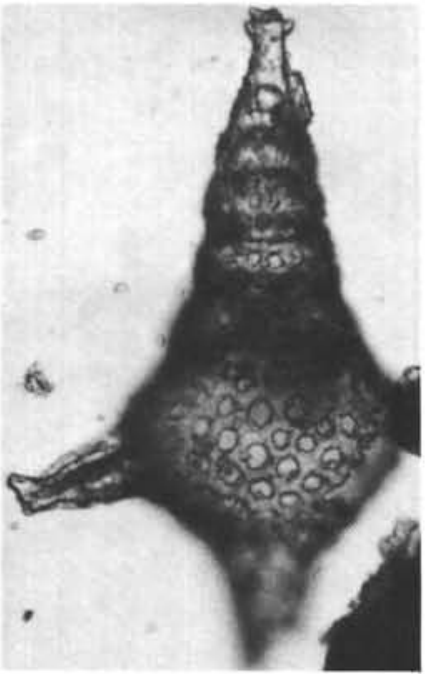

6

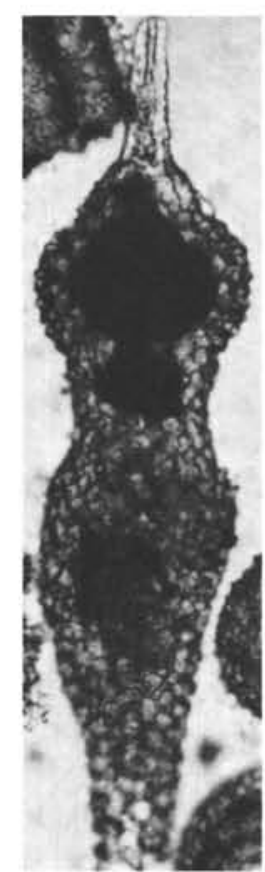

8

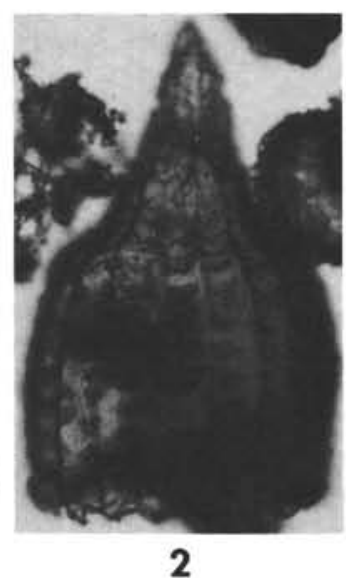

2

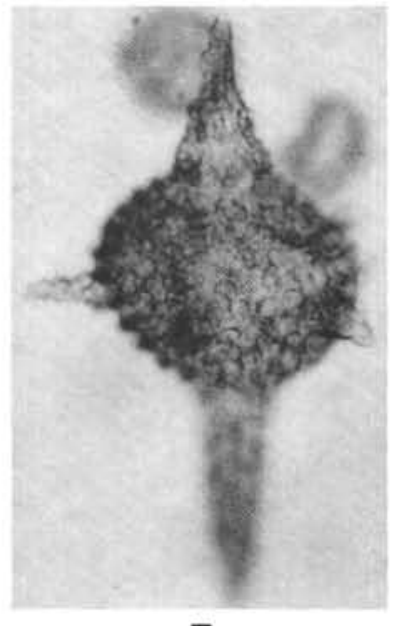

7

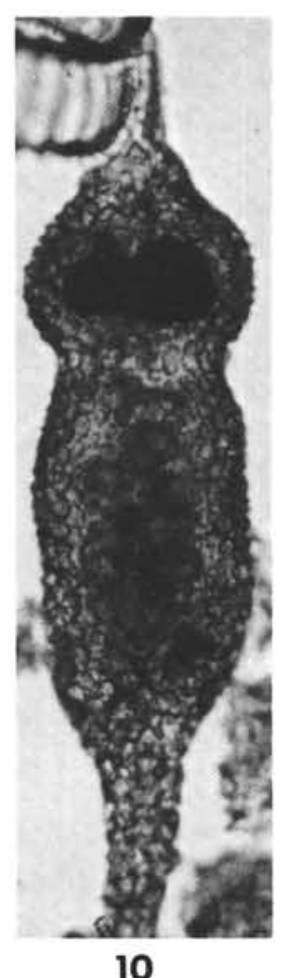

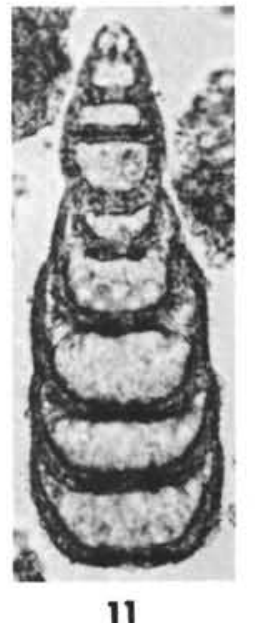

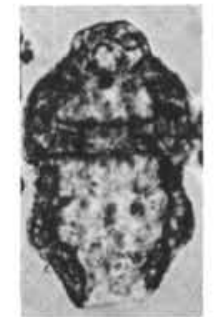

12

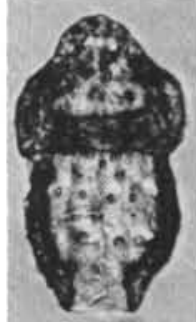

13

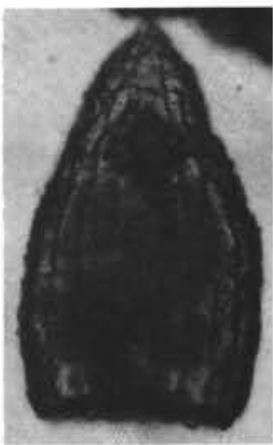

5

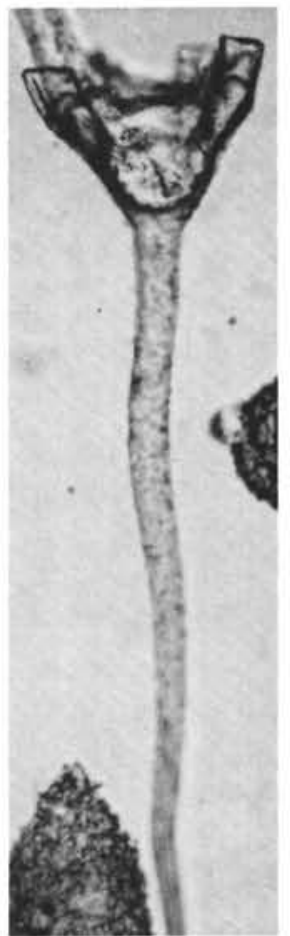

15

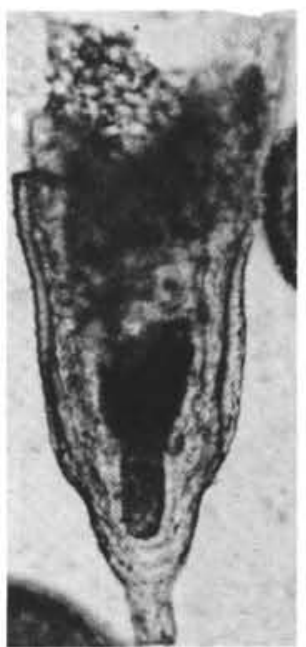

16 


\section{PLATE 14}

Cretaceous radiolarians from Site 256 (Figures 1, 2) and 258.

Figures 1-4, 8-11 magnified $\times 235$.

Figure 1 Dictyocephalus sp.

DSDP 256-6-3, 55-59 cm, Ph.1, S8/1.

Figure 2 Dictyomitra torquata

$$
\text { DSDP 256-6-3, 55-59 cm, Sl.2, V18/2. }
$$

Figure 3 Archaeospongoprunum cortinaensis DSDP 258-9-1, 50-51 cm, Sl.2, S34/0.

Figure $4 \quad$ Spongopyle insolita group DSDP 258-9-1, 50-55 cm, S1.2, V15/3.

Figures 5-8 Hagiastrin cf. Staurolonchidium tuberosum 5. DSDP 258-7-1, 161-165 cm, Cs.1, D17/0 (magnification $\times 90$ );

6. DSDP $258-7-1,161-165 \mathrm{~cm}$, Cs.1, P39/3 (magnification $\times 90$ );

7. DSDP 258-7-2, 55-60 cm, Cs.1, G29/3 (magnification $\times 150$ );

8. Specimen lacking arms, showing internal shells and connecting bars

DSDP 258-7-1, 161-165 cm, Cs.1, R30/0.

Figure 9 Bathropyramis sp.

DSDP 258-9-1, $50-55 \mathrm{~cm}, \mathrm{Sl} .3, \mathrm{~V} 25 / 0$.

Figure $10 \quad$ Cyrtocalpis operosa

DSDP 258-9-1, 50-55 cm, Sl.1, K28/4.

Figure 11 Dictyomitra macrocephala

DSDP 258-13-2, 48-52 cm, Sl.1, W23/0. 
PLATE 14
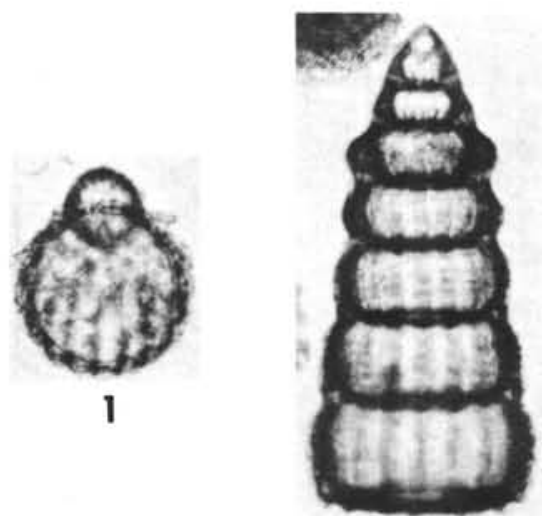

2

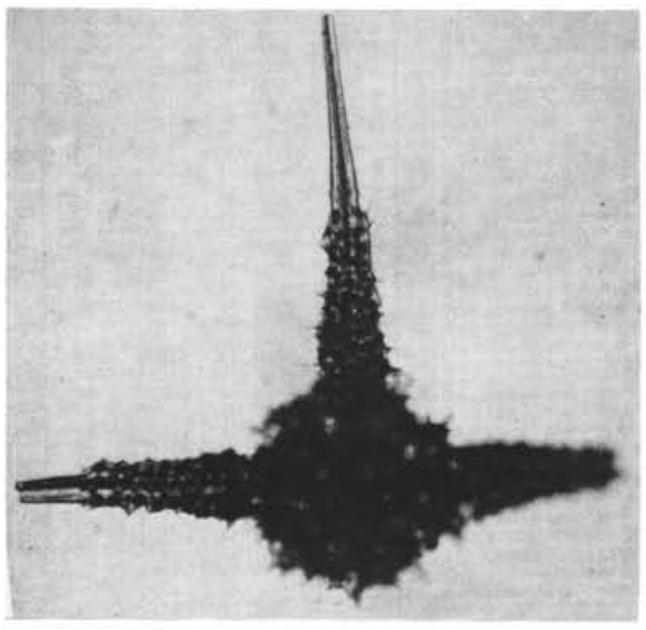

6

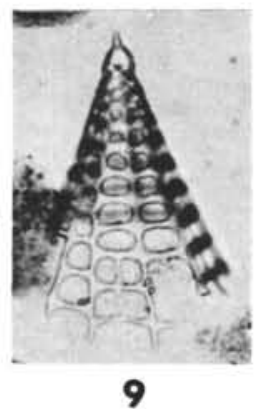

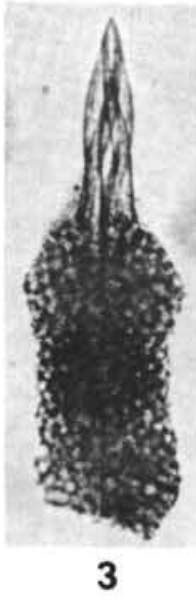
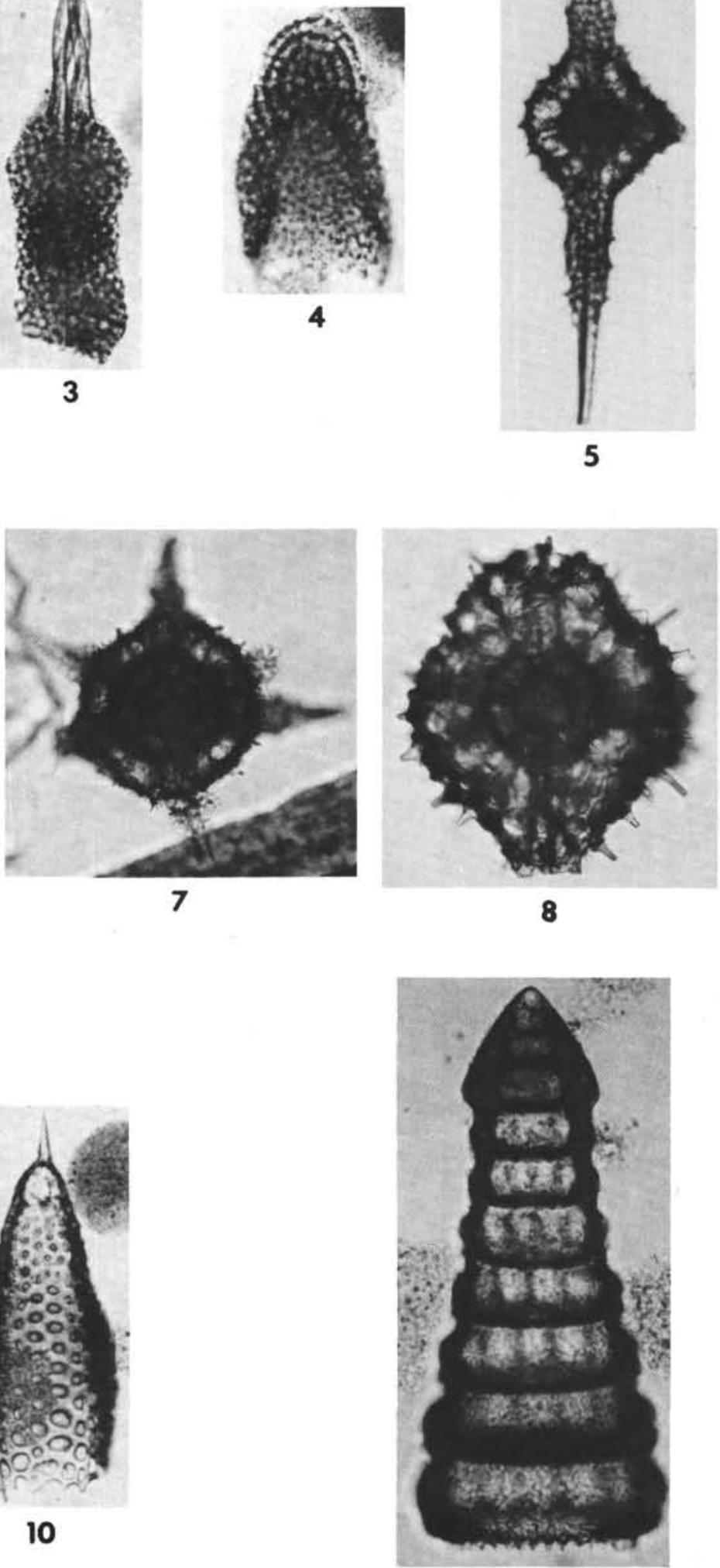

11

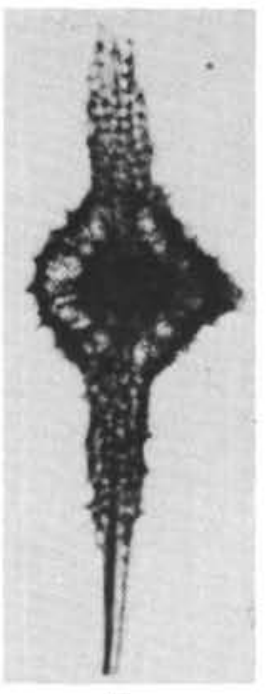

5

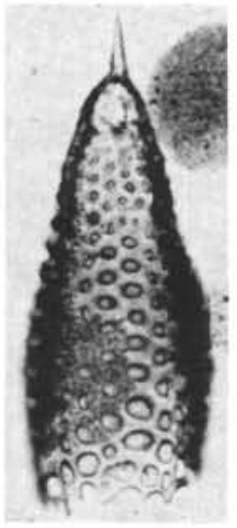

10 
PLATE 15

Cretaceous radiolarians from Site 258.

All figures magnified $\times 235$.

Figures 1-3 Dictyomitra sp. cf. D. regina

1. DSDP 258-10-1, 134-139 cm, Ph.1, O29/4;

2. DSDP 258-7-1, 101-105 cm, Sl.1, R36/0;

3. DSDP 258-9-1, 50-55 cm, Sl.3, P44/1.

Figure $4 \quad$ Solenotryma sp.

DSDP 258-9-1, 50-55 cm, SI.1, R27/2.

Figure $5 \quad$ Stichomitra asymbatos group

DSDP 258-7-1, 101-105 cm, Cs.1, P24/1.

Figures 6-9 Unidentified theoperid, similar to one occurring in the Coniacian-Santonian of Roumania (illustrated in Figure 10)

6. DSDP 258-12-2, 60-64 cm, Sl.2, T9/4;

7. DSDP $258-12-2,60-64 \mathrm{~cm}, \mathrm{Sl} .2, \mathrm{~S} 37 / 1$;

8. DSDP 258-12-2, 60-64 cm, Sl.1, X32/3;

9. DSDP 258-13-2, $48-52 \mathrm{~cm}, \mathrm{~S} 1.2, \mathrm{~S} 42 / 1$.

Figure $10 \quad$ Unidentified theoperid

Dumitrica sample 1627 (coll. 19 May 1970)

Bretelin Valley, Cirjiti, Hunedoara District,

Roumania

Coniacian-Santonian, Sl.1, D38/4.

Figure $11 \quad$ Amphipyndax stocki

DSDP 258-7-1, 101-105 cm, Sl.1, H13/4. 
PLATE 15
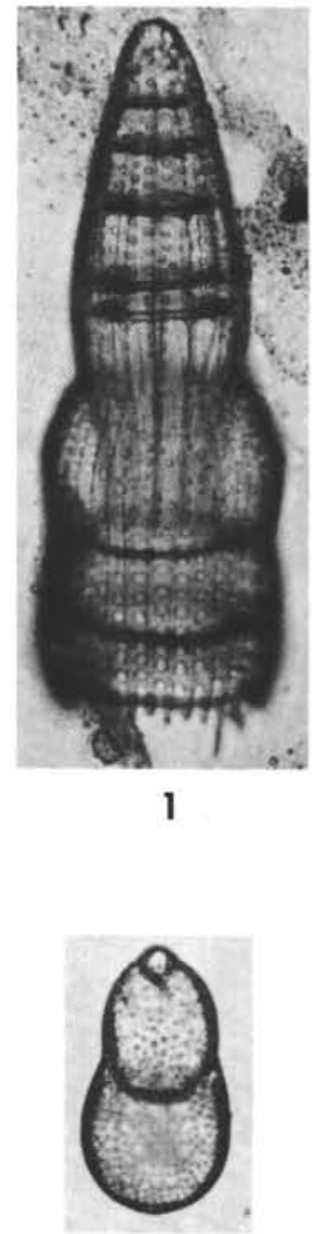

4

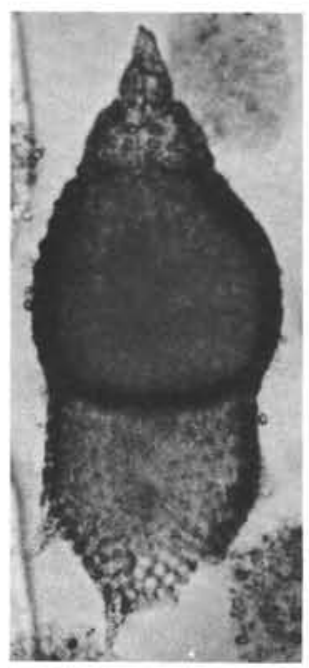

8

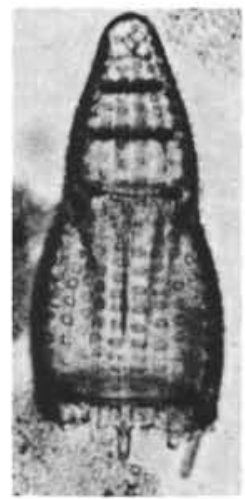

2

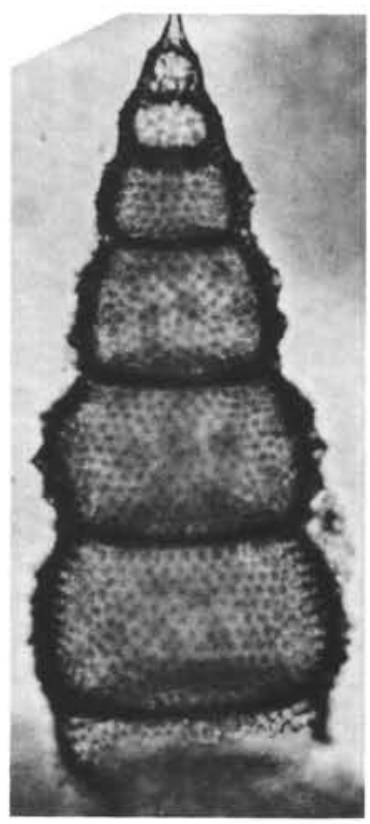

5

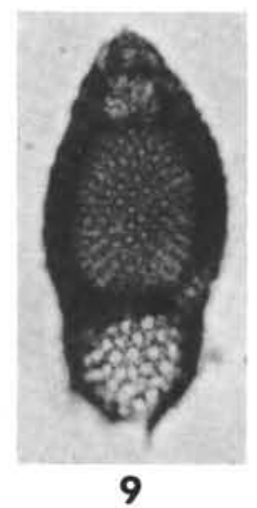

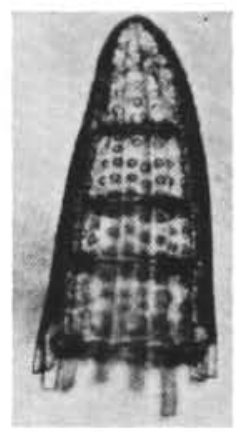

3

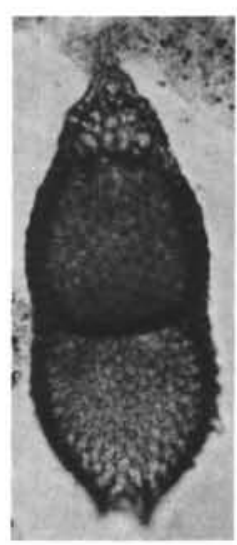

6
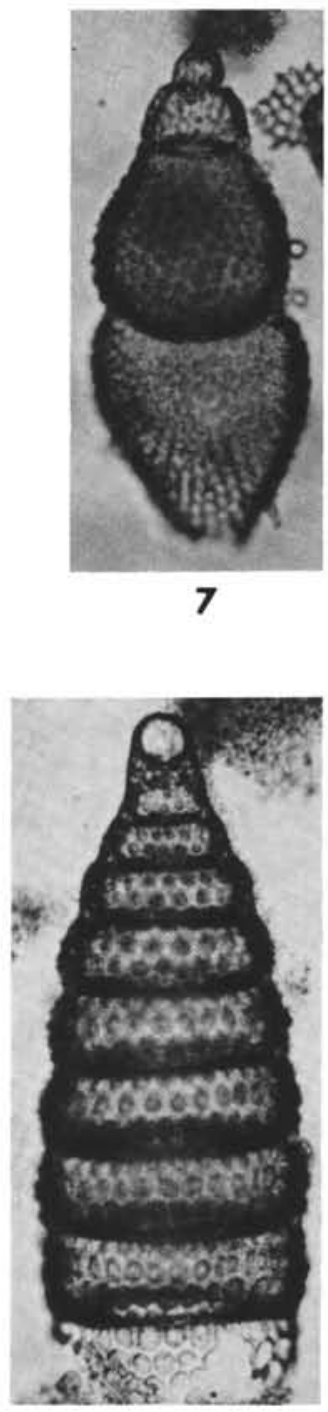

11 